OPEN ACCESS

Edited by:

Elena Adinolfi,

University of Ferrara, Italy

Reviewed by:

Karine Rachel Prudent Breckpot, Vrije University Brussel, Belgium

Darina Ocadlikova,

University of Bologna, Italy

*Correspondence:

Nianmin QI

Drqi@163.com

Yuehong Wu

wuyuehong2003@163.com

Specialty section:

This article was submitted to

Molecular and Cellular Oncology,

a section of the journal

Frontiers in Cell and Developmental

Biology

Received: 27 March 2021

Accepted: 11 May 2021

Published: 28 June 2021

Citation:

Salah A, Wang H, Li Y, Ji M

Ou W-B, Qi N and Wu Y (2021)

Insights Into Dendritic Cells in Cancer

Immunotherapy: From Bench to

Clinical Applications.

Front. Cell Dev. Biol. 9:686544.

doi: 10.3389/fcell.2021.686544

\section{Insights Into Dendritic Cells in Cancer Immunotherapy: From Bench to Clinical Applications}

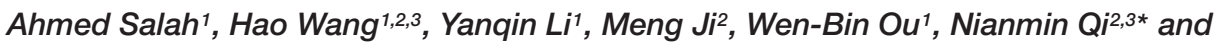 \\ Yuehong $\mathrm{Wu}^{1 *}$
}

\begin{abstract}
'Department of Biochemistry and Molecular Biology, College of Life Science and Medicine, Zhejiang Sci-Tech University, Hangzhou, China, ${ }^{2}$ Hangzhou Biaomo Biosciences Co., Ltd., Hangzhou, China, ${ }^{3}$ Asia Stem Cell Therapies Co., Limited, Shanghai, China
\end{abstract}

Dendritic cells (DCs) are efficient antigen-presenting cells (APCs) and potent activators of naiive $T$ cells. Therefore, they act as a connective ring between innate and adaptive immunity. DC subsets are heterogeneous in their ontogeny and functions. They have proven to potentially take up and process tumor-associated antigens (TAAs). In this regard, researchers have developed strategies such as genetically engineered or TAApulsed DC vaccines; these manipulated DCs have shown significant outcomes in clinical and preclinical models. Here, we review DC classification and address how DCs are skewed into an immunosuppressive phenotype in cancer patients. Additionally, we present the advancements in DCs as a platform for cancer immunotherapy, emphasizing the technologies used for in vivo targeting of endogenous DCs, ex vivo generated vaccines from peripheral blood monocytes, and induced pluripotent stem cell-derived DCs (iPSC-DCs) to boost antitumoral immunity.

Keywords: dendritic cells, cancer vaccines, cancer immunotherapy, induced pluripotent stem cells, iPSC-DCs

\section{INTRODUCTION}

Cancer evades immune surveillance as one of its hallmarks and prevents the immune system from tumor eradication (Hanahan and Weinberg, 2011; Mittal et al., 2014). Thus, immunotherapy, relying on cell therapy, cancer inhibitory signal antagonists, nanoparticle-based vaccines, oncolytic viruses, and immunogenic cell death-inducing agents, is considered a cornerstone in cancer treatment (Helmy et al., 2013; Yang, 2015; Kranz et al., 2016; Van der Jeught et al., 2018; Riley et al., 2019; Vanmeerbeek et al., 2020; Malvehy et al., 2021). In general, cell-based cancer immunotherapy can be divided into two subclasses, active and passive immunotherapies. Active immunotherapy utilizes antigen-presenting cells (APCs) such as dendritic cells (DCs) to boost patients' immune system to fight against cancer (Van Lint et al., 2014; Jansen et al., 2020). However, passive immunotherapy mostly involves immunization with $\mathrm{T}$ cells to induce immune-mediated tumor rejection, including adoptive transfer of tumor-infiltrating lymphocytes or chimeric antigen receptor T (CAR-T) cell therapy, which has shown significant outcomes in treating hematological malignancies (Rosenberg et al., 2011; Fry et al., 2018; Depil et al., 2020). Cancer vaccines are one type of immunotherapeutic strategies that have shown promising results in a personalized manner. GVAX is one of the first tested vaccines against pancreatic cancer, and it is composed of the 
irradiated tumor cell-expressing granulocyte-macrophage colony-stimulating factor (GM-CSF) (Le et al., 2015; Yarchoan et al., 2020).

Dendritic cells are a type of innate immune cells and are potent APCs. They play a central role in immune-mediated cancer elimination through antigen presentation and T-cell priming (Steinman, 2007, 2012; Eisenbarth, 2019; Sa-Nunes and Oliveira, 2021). After tumor-associated antigen (TAA) phagocytosis, antigens are processed by two pathways, the cytosolic pathway and vacuolar pathway, by which they are digested into peptides and loaded onto the major histocompatibility complex (MHC) class I. The TAA-MHC I complex is then transported to the DC surface. When DC-presenting TAAs migrate and reach the lymph nodes, they are capable of priming $\mathrm{T}$ cells and triggering antitumor immunity (Joffre et al., 2012; Perez and De Palma, 2019). Before maturation, DCs have a high phagocytic capacity. On the other hand, mature DCs have a lower endocytic ability; express greater levels of co-stimulatory molecules [such as cluster of differentiation 80 (CD80), inducible T-cell co-stimulator ligand (ICOSL), programmed cell death ligand-1 (PD-L1), PDL2, CD31, CD27, and CD70], and C-C chemokine receptor type 7 (CCR7); and secrete high levels of pro-inflammatory cytokines [such as interleukin-12 (IL-12) and tumor necrosis factor-alpha (TNF- $\alpha)$ ] (Patente et al., 2018). Accordingly, scientists have developed modified DCs as an effective cancer vaccine approach, leveraging the DCs' ability to induce both cellular and humoral immunity (Figure 1).

Dendritic cell vaccines were earlier used against highly immunogenic cancers such as melanoma (Nestle et al., 1998;

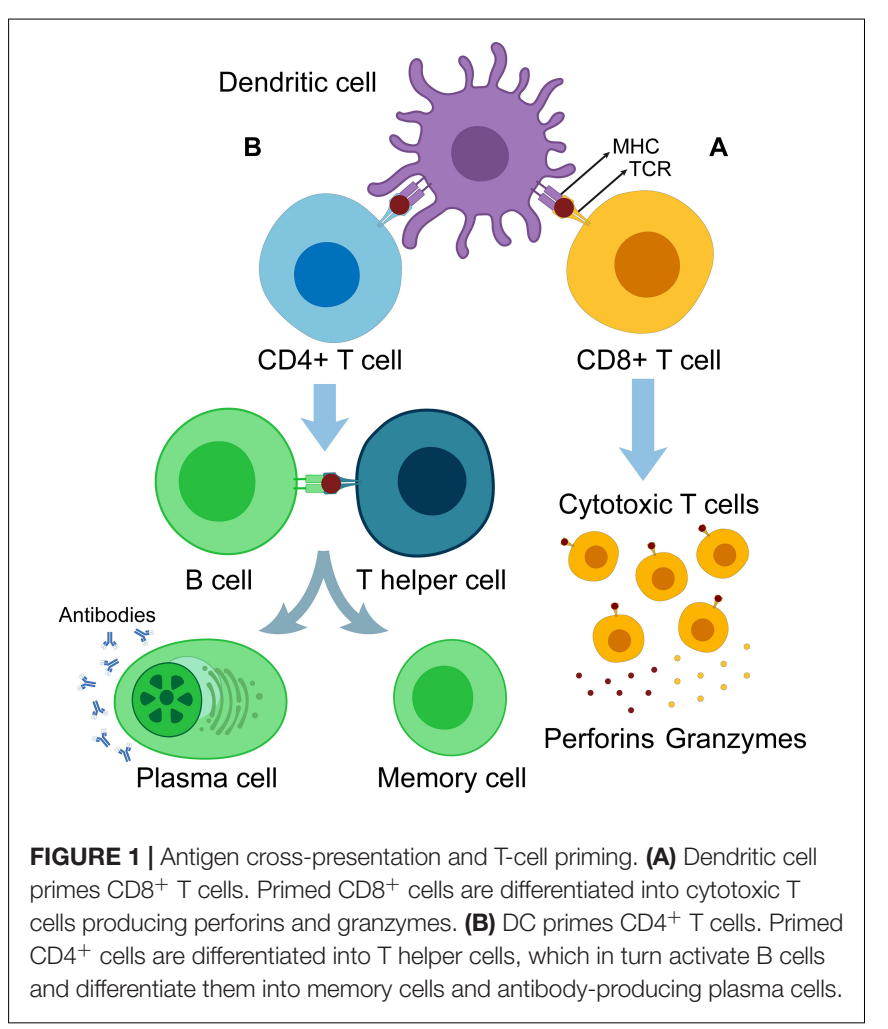

Butterfield et al., 2003). Later on, they have been extensively used in several clinical trials (Table 1). Commonly, patientderived monocytes or hematopoietic stem cells are collected and differentiated in vitro into DCs. Then, DCs are pulsed with TAAs or tumor lysates and cultured with maturation cytokines (Santos and Butterfield, 2018; Yang et al., 2019). This method is hindered by the low amount of immune cells in cancer patients (Tjomsland et al., 2010), which could be a side effect of other treatments such as radiation or chemotherapy. The use of monocyte-derived DCs (MoDCs) obtained from healthy donors can overcome this problem. Other TAA loading strategies include targeting DCs with viral vectors (Goyvaerts et al., 2014; Sharma et al., 2018) and mRNA-engineered DCs (Benteyn et al., 2015; Willemen et al., 2020).

Fortunately, after Takahashi and Yamanaka (2006) generated induced pluripotent stem cells (iPSCs) from mouse fibroblasts by introducing four transcription factors (OCT4, SOX2, KLF4, and $c-M Y C)$, iPSCs have become a template to generate DCs in quantities suitable to produce anticancer efficacy (Senju et al., 2011b; Sachamitr et al., 2014; Kitadani et al., 2018). Furthermore, in vivo targeting of DCs, in which nanoparticles, antibodies, viral vectors, and RNA are used as carriers to deliver TAAs, co-stimulatory molecules, or adjuvants to stimulate endogenous DCs (VandenDriessche et al., 2002; Dullaers et al., 2006; Diken et al., 2011; Cubillos-Ruiz et al., 2012; Kreutz et al., 2013; Van Lint et al., 2016), is considered an efficient state-of-theart approach to bypass leukapheresis inconveniency and the laborious differentiation and maturation protocols. Increasing efforts to understand DC biology will help to derive better DC vaccines either as a single therapy or in combination with other treatment regimens. This review provides a brief overview of the main DC subsets and illustrates how DC and cancer cell crosstalk in the tumor microenvironment (TME) correlates with a positive or negative prognosis. Lastly, we discuss the cuttingedge approaches to using DCs in cancer immunotherapy.

\section{SUBSETS}

DC subpopulations are classified according to their ontogeny, morphology, function, marker expression, and cytokine secretion into three main subtypes: MoDCs, plasmacytoid DCs (pDCs), and conventional DCs (cDCs), which are further divided into type 1 ( $\mathrm{cDC} 1 \mathrm{~s})$ and type $2(\mathrm{cDC} 2 \mathrm{~s})$.

\section{MoDCs}

In response to inflammation, monocytes are differentiated into DCs (Collin and Bigley, 2018). MoDCs are generated ex vivo in vast amounts from $\mathrm{CD}_{1} 4^{+}$monocytes or $\mathrm{CD} 34^{+}$ hematopoietic stem cells through culturing with IL-4 and GM-CSF (Mastelic-Gavillet et al., 2019), which allows for a better understanding of DC biology. T-cell-directed differentiation by DCs is largely dependent on the maturation signal. MoDCs treated with toll-like receptor (TLR) agonists promote Th1 activation. For example, MoDCs electroporated with a polyinosinic: polycytidylic acid [poly(I:C)] analog [poly(I:C12U)], which is a TLR3 agonist, promoted CD4 ${ }^{+}$T-cell 
TABLE 1 | Clinical trials utilizing DC vaccines in cancer immunotherapy.

\begin{tabular}{|c|c|c|c|}
\hline Intervention & Cancer type & Clinical response & References \\
\hline $\begin{array}{l}\text { Autologous DCs loaded with } \\
\text { vaccinia-CEA-MUC-1-TRICOM } \\
\text { (PANVAC-V) + autologous DCs loaded with } \\
\text { fowl pox-CEA-MUC-1-TRICOM (PANVAC-F) }\end{array}$ & $\begin{array}{l}\text { Resected hepatic or } \\
\text { pulmonary metastases } \\
\text { of colorectal carcinoma }\end{array}$ & $\begin{array}{l}13 \text { of } 16 \text { patients achieved } 2 \text { years of } \\
\text { recurrence-free survival }\end{array}$ & Morse et al., 2013 \\
\hline Sipuleucel-T & Prostate cancer & $\begin{array}{l}\text { Median OS in treated patients is } 25.8 \text { months } \\
\text { compared to } 21.7 \text { in placebo }\end{array}$ & Small et al., 2014 \\
\hline Autologous DCs loaded with TAAs & Melanoma & $\begin{array}{l}\text { Out of } 14 \text { patients, } 4 \text { achieved PFS ( } 12-35 \text { months), } \\
5 \text { showed OS ( } 22-40 \text { months), and } 4 \text { achieved SD }\end{array}$ & Schreibelt et al., 2016 \\
\hline TriMixDC-MEL & Melanoma & $\begin{array}{l}-71 \% \text { of the treated patients were alive and disease } \\
\text { free vs. } 35 \% \text { of the control } \\
\text {-The median time to non-salvageable disease } \\
\text { recurrence in treated patients were higher than in } \\
\text { control }\end{array}$ & Jansen et al., 2020 \\
\hline TriMixDC-MEL & Melanoma & $\begin{array}{l}\text {-Out of } 15 \text { patients, } 2 \text { achieved CR, } 4 \text { achieved SD, } \\
\text { and } 7 \text { showed PD -Five out of } 15 \text { patients achieved } \\
\text { PFS ( } 23.6-34 \text { months) }\end{array}$ & Wilgenhof et al., 2013 \\
\hline WT1 mRNA-electroporated DCs & Acute myeloid leukemia & $\begin{array}{l}\text {-Six of } 30 \text { patients achieved CR } 107.6 \text { (months } \\
\text { median duration), and } 19 \text { had a disease relapse }-15 \\
\text { of these } 19 \text { had a salvage therapy, and } 73.3 \% \text { of } \\
\text { them achieved a second CR }\end{array}$ & Anguille et al., 2017 \\
\hline $\begin{array}{l}\text { Autologous DCs loaded with allogeneic } \\
\text { non-small-cell lung cancer cells }\end{array}$ & $\begin{array}{l}\text { Non-small-cell lung } \\
\text { cancer }\end{array}$ & $\begin{array}{l}-20 \text { of } 32 \text { patients were alive } 5 \text { years post } \\
\text { vaccination }-22 \text { of } 32 \text { showed immunologic } \\
\text { response within } 6 \text { months of vaccination }\end{array}$ & NCT00103116 \\
\hline Peptide-pulsed DCs + indinavir & $\begin{array}{l}\text { Ewing's sarcoma and } \\
\text { rhabdomyosarcoma }\end{array}$ & $\begin{array}{l}43 \% \text { of the treated patients achieved a } 5 \text {-year OS, } \\
\text { and } 31 \% \text { achieved a } 5 \text {-year EFS }\end{array}$ & NCT00001566 \\
\hline $\begin{array}{l}\text { Adenovirus-p53-transduced } \\
\text { DCs + 1-methyl-d-tryptophan }\end{array}$ & Breast cancer & $\begin{array}{l}1 \text { of } 21 \text { patients achieved complete response, } 7 \\
\text { showed partial response, and } 2 \text { achieved stable } \\
\text { disease }\end{array}$ & NCT01042535 \\
\hline CEA mRNA-pulsed DCs & CEA-expressing cancer & $\begin{array}{l}3 \text { of } 23 \text { showed SD, } 1 \text { showed } C R \text {, and } 18 \text { showed } \\
\text { PD }\end{array}$ & Morse et al., 2003 \\
\hline Tumor mRNA-pulsed DCs & Brain cancer & $\begin{array}{l}2 \text { of } 5 \text { patients achieved SD, none showed PR, and } \\
3 \text { showed PD }\end{array}$ & Caruso et al., 2004 \\
\hline $\begin{array}{l}\text { Peptide-loaded DCs }+ \text { dasatinib administered } \\
\text { at the same time }\end{array}$ & Metastatic melanoma & $\begin{array}{l}\text {-Four of six patients had partial response, and } 2 \text { out } \\
\text { of } 6 \text { had progressed disease -The calculated ORR } \\
\text { in } 6 \text { participants is } 0.6667\end{array}$ & NCT01876212 \\
\hline
\end{tabular}

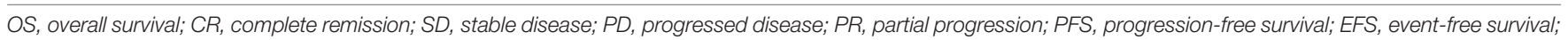
$\mathrm{ORR}$, overall response rate; CEA, carcinoembryonic antigen.

expansion and induced their differentiation toward Th1 cells (Kaisho and Akira, 2003; Michiels et al., 2006). Electroporation of MoDCs with CD40L and/or constitutively active TLR4 (caTLR4) encoding mRNA, but not with CD70 mRNA, induces $\mathrm{CD} 4^{+}$ T-cell differentiation into Th1 cells. However, electroporation of DCs with CD40L, CD70, and caTLR4 mRNA (TriMixDC) in addition to melan $\mathrm{A}$ antigen mRNA induces antigen-specific $\mathrm{CD}^{+}$cytotoxic $\mathrm{T}$ cells. Additionally, MoDCs treated with curdlan, a dectin- 1 agonist, induce $\mathrm{CD} 4^{+}$T-cell skewing toward Th1 and Th17 cells (Bonehill et al., 2008, 2009; Dragicevic et al., 2012). However, ex vivo generated MoDCs are transcriptionally distinct from their primary counterparts (Helft et al., 2015), and their migration capacity and efficacy are debated (Morse et al., 1999; Shinde et al., 2018); nevertheless, they remain the cornerstone of cancer vaccine studies due to their accessibility, rapid differentiation, and maturation protocols compared with other subsets (Shinde et al., 2018; Tanyi et al., 2018). Ontogeny studies revealed that inflammatory DCs are the closest phenotype to MoDCs (Segura et al., 2013; Reynolds and Haniffa, 2015).
Inflammatory DCs express FceRI, CD11c, CD11b, CD14, CD1a, and CD209, and they are described in patients with cancer, psoriasis, and atopic dermatitis, and in the synovial fluid of patients with rheumatoid arthritis (Wollenberg et al., 1996; Segura and Amigorena, 2013; Segura et al., 2013).

\section{pDCs}

Plasmacytoid DCs are one type of bone marrow-derived DCs (BMDCs), which arise from common DC precursors and lymphoid precursors (Naik et al., 2007; Geissmann et al., 2010; Rodrigues et al., 2018). pDCs are known for their ability to produce high levels of type I interferon (IFN) upon stimulation of TLR7 and TLR9, and they play a crucial role during viral infections (Reizis et al., 2011; Mitchell et al., 2018). They are characterized by the expression of CD4, CD123, CD303, CD304, blood-derived cell antigen-2 (BDCA-2), human leukocyte antigen-DR (HLA-DR), and TLR7/TLR9 (Swiecki and Colonna, 2015; Villani et al., 2017; Wculek et al., 2020). Matsui et al. (2009) showed that pDCs are further divided into two subtypes 
based on the expression of $\mathrm{CD} 2$, in which the $\mathrm{CD} 2$ (high) pDC subpopulation expresses higher levels of CD80 and IL-12 p40. pDCs have limited antigen-presenting potential (Chiang et al., 2016), and their presence in the TME is associated with poor cancer prognosis as they induce tumor progression through stimulation of ICOSL, which in turn stimulates regulatory T (Treg) cells (Conrad et al., 2012; Lombardi et al., 2015). On the other hand, stimulated pDCs have shown promising results as cancer vaccines. In clinical and preclinical melanoma models, different strategies of antigen delivery or loading onto pDCs resulted in significant type I IFN production, antigenspecific T-cell priming, and superior chemoattractive properties to cDC2s, eliciting antitumor activity (Tel et al., 2013; Kranz et al., 2016; van Beek et al., 2020). Conversely, Salio et al. (2004) showed that T-cell priming is independent of type I IFN production. Another study suggested that the presence of pre-classical DCs (pre-CDCs), the intermediate precursors to $\mathrm{cDC} 1 \mathrm{~s}$ and $\mathrm{cDC} 2 \mathrm{~s}$, in the $\mathrm{pDC}$ subpopulation might reflect the responsibility for Th1-cell induction and cross-presentation capability (Patente et al., 2018).

\section{cDC1s}

Similar to pDCs, $c D C 1 s$, and $\mathrm{cDC} 2 \mathrm{~s}$ arise from common dendritic progenitors (CDPs) (Patente et al., 2018). cDC1s express CD141, XCR1, and CLEC9A (Poulin et al., 2010; Wculek et al., 2020). They have superior antigen presentation activity on MHC I to cytotoxic T cells (Palucka et al., 2010), thus activating Th1 and CD8 ${ }^{+}$cells (Martinez-Lopez et al., 2015; Laoui et al., 2016). cDC1s have profound antitumor functions, and their presence in the TME correlates with better prognosis and survival rate (Sluijter et al., 2015; Bottcher et al., 2018; Cancel et al., 2019; Zilionis et al., 2019). In this light, the need to generate cDC1s in vitro that resemble primary $\mathrm{CDC} 1 \mathrm{~s}$ in a suitable quantity has gained researchers' interest. The Notch signaling pathway was identified as a potent inducer of cDC differentiation (MartinGayo et al., 2017). Culturing of bone marrow progenitors in a medium containing FMS-like tyrosine kinase 3 ligand (FLT3L) for 3 days followed by co-culturing on monolayers of OP9 stromal cells expressing the Notch ligand Delta-like 1 (OP9DL1) induced $\mathrm{cDC} 1$ differentiation with marker expressions $\left(\mathrm{CD} 103^{+}, \mathrm{Dec}_{205^{+}}\right.$, and $\left.\mathrm{CD} 8 \alpha^{+}\right)$resembling wild-type cDC1s. The presence of OP9-DL1 produced $\mathrm{cDC} 1 \mathrm{~s}$ with preferential migration potential compared to other methods (Lee et al., 2015; Kirkling et al., 2018).

Ex vivo loading of primary $\mathrm{cDC} 1 \mathrm{~s}$ with tumor cell lysates induced $\mathrm{CD} 8^{+}$and $\mathrm{CD} 4^{+}$T-cell infiltration and reduced tumor progression in engrafted tumor models (Wculek et al., 2019). IFN regulatory factor 8 (Irf8) (Guilliams et al., 2016) and basic leucine zipper transcriptional factor ATF-like 3 (Batf3) (Poulin et al., 2012; Grajales-Reyes et al., 2015) are critical transcriptional factors in the development of $\mathrm{cDC} 1 \mathrm{~s}$ and are essential for tumor rejection (Theisen et al., 2019). In Batf3 $3^{-/-}$mice, DCs were not able to mediate rejection of highly immunogenic tumors as they lack cross-presentation potential with subsequent impairment of cytotoxic T-cell activity (Hildner et al., 2008). Transgenic expression of Irf8 into Batf3-deficient mice allowed the development of $\mathrm{cDC} 1 \mathrm{~s}$ and restored their cross-presentation function. However, these DCs failed to mediate rejection of fibrosarcoma (Theisen et al., 2019). These results indicate that immunogenic rejection of tumors is Batf3 dependent but not limited to DC ability to cross-present tumor antigens, and there might be other mechanisms involved, such as the ability of $\mathrm{cDC} 1 \mathrm{~s}$ to communicate with other immune cells through the secretion of CXC-chemokine ligand 9 (CXCL9) and CXCL10, which induce recruitment and infiltration of $\mathrm{T}$ cells at the tumor site (Perez and De Palma, 2019). Immune rejection of tumors also lay under the effect of CCR7 expression on CDC1s. CCR7 expression promotes TAA-carrying $\mathrm{cDC} 1$ migration to draining the lymph node where $\mathrm{CD} 8^{+}$priming occurs, boosting antitumor response (Roberts et al., 2016; Wang et al., 2016).

\section{cDC2s}

CDC2 distribution is found to be lower than that of other DC types. They are characterized by CD172a, CD11c, CD11b, and CD1c (O'Keeffe et al., 2015; Wculek et al., 2020). Like cDC1s, cDC2s have shown antitumor efficacy. They act via antigen presentation on MHC II to $\mathrm{CD} 4^{+} \mathrm{T}$ cells, promoting T-cell differentiation into Th1, Th2, and Th17 cells (Leal Rojas et al., 2017; Eisenbarth, 2019). Studies have shown that Irf4 is essential for CDC2 activity and Th2-cell differentiation, which stimulates humoral immunity and promotes B-cell proliferation (Schlitzer et al., 2013). In mouse models, loss of Irf4 reduced cDC2 function and defected Th2-cell differentiation (Schlitzer et al., 2013; Williams et al., 2013; Binnewies et al., 2019). In the context of the cDC2 ability to induce antitumor responses, $\mathrm{CDC} 2 \mathrm{~s}$ were found to efficiently prime $\mathrm{CD} 4^{+} \mathrm{T}$ cells in vaccinated mice and induce Th17-cell differentiation, and most noteworthy, they were able to repolarize tumor-associated macrophages (TAMs) from M2 protumoral phenotype into M1 antitumor phenotype (Laoui et al., 2016). Additionally, cDC2 vaccines pulsed with tumor antigens were tested in clinical trials, and they showed effective and safe antitumor responses against metastatic melanoma and metastatic prostate cancer (Prue et al., 2015; Schreibelt et al., 2016).

\section{MALFUNCTION IN CANCER PATIENTS}

It is well known that tumors and TME manipulate the immune system to favor their persistence and progression. In the case of colorectal cancer, the presence of elevated numbers of tumorassociated DCs correlated with poor prognosis (Jochems and Schlom, 2011). Several mechanisms were found to perturb DC functions. For example, PD-L1 is highly expressed in tumor-infiltrating DCs, inhibiting T-cell activation and cytokine production. DC activity was restored upon PD-1/PD-L1 blockade (Salmon et al., 2016). Another mechanism is through upregulation of T-cell immunoglobulin and mucin domaincontaining-3 (TIM-3) protein on DCs, which inhibits sensing of danger signals (Maurya et al., 2014; de Mingo Pulido et al., 2018). Michielsen et al. (2011) reported that VEGF, CCL1, CCL2, and CXCL5 presence in conditioned medium from colorectal cancer explants inhibited DC maturation and IL$12 \mathrm{p}$ production while increasing IL-10 secretion. Melanomas 
expressing $\beta$-catenin were found to induce resistance to immunotherapeutics, reduce infiltrating $\mathrm{cDC} 1 \mathrm{~s}$ and $\mathrm{T}$ cells, and promote tumor growth (Spranger et al., 2015). Moreover, the presence of prostaglandin E2 (PGE2) stimulated tumor growth by impairing the accumulation of intratumoral $\mathrm{CD}_{103}{ }^{+} \mathrm{DCs}$ (Zelenay et al., 2015).

Metabolic dysfunction can also influence DC maturation in cancer patients. Hypoxia, lactic acid production, and decreased $\mathrm{pH}$ impair normal DC function. In vitro cultures of prostate cancer or melanoma cells produced high levels of lactic acid, which was associated with modulation of DC differentiation and maturation (Gottfried et al., 2006). Other TME-derived products induce lipid peroxidation, which activates the endoplasmic reticulum stress response factor via spliced $\mathrm{X}$-box-binding protein 1, leading to lipid accumulation in DCs (Tyurin et al., 2011; Cubillos-Ruiz et al., 2015). Accumulation of lipid particles inhibits the peptide-MHC I complex migration to the DC surface and impairs cross-presentation potential to T cells, blocking their activity (Herber et al., 2010; Ramakrishnan et al., 2014; Veglia et al., 2017).

Infiltrating pDCs are incapable of type I IFN production and can also stimulate Treg-cell expansion through the expression of indoleamine 2,3-dioxygenase (IDO) and ICOSL, which enhance tumor progression (Ito et al., 2007; Aspord et al., 2013). In many cancer patients, high levels of infiltrating pDCs are linked to poor prognosis (Lombardi et al., 2015; Saadeh et al., 2016). Tumor DCs have shown lower antigen-trafficking potential due to controlled CCR7 expression (Roberts et al., 2016), resulting in decreased ability to prime $\mathrm{T}$ cells in lymph nodes. Moreover, signal transducer and activator of transcription 3 (STAT3) phosphorylation, activated by IL-6 and IL-10 in chronic lymphocytic leukemia patients' sera, induces suppressor of cytokine signaling 5 expression, which in turn inhibits STAT6 activation (an essential molecule for MoDC differentiation), preventing monocyte differentiation and maturation (Toniolo et al., 2016; Kitamura et al., 2017).

\section{DCS IN CANCER IMMUNOTHERAPY}

As previously mentioned, DCs are the most potent APCs that promote cellular and humoral antitumor immunity, making immunotherapy-based DC vaccines, with either ex vivo generated DCs or in vivo targeting modalities, an active area of research (Figure 2). That's why researchers are working to augment their efficacy, providing new paradigms of cancer vaccines, which could be considered as potential candidates in various clinical settings.

\section{MoDC Vaccines}

Based on the understanding of DC biology and their antigen presentation and $\mathrm{T}$-cell activation potential, numerous preclinical and clinical studies utilizing DCs in cancer immunotherapy have been undertaken (Steinman and Banchereau, 2007). Most clinical trials relied on DCs generated ex vivo from blood monocytes. Usually, IL-4 and GM-CSF are used to induce DC differentiation from monocytes in 5-7 days (Dauer et al., 2003; Mohty et al.,

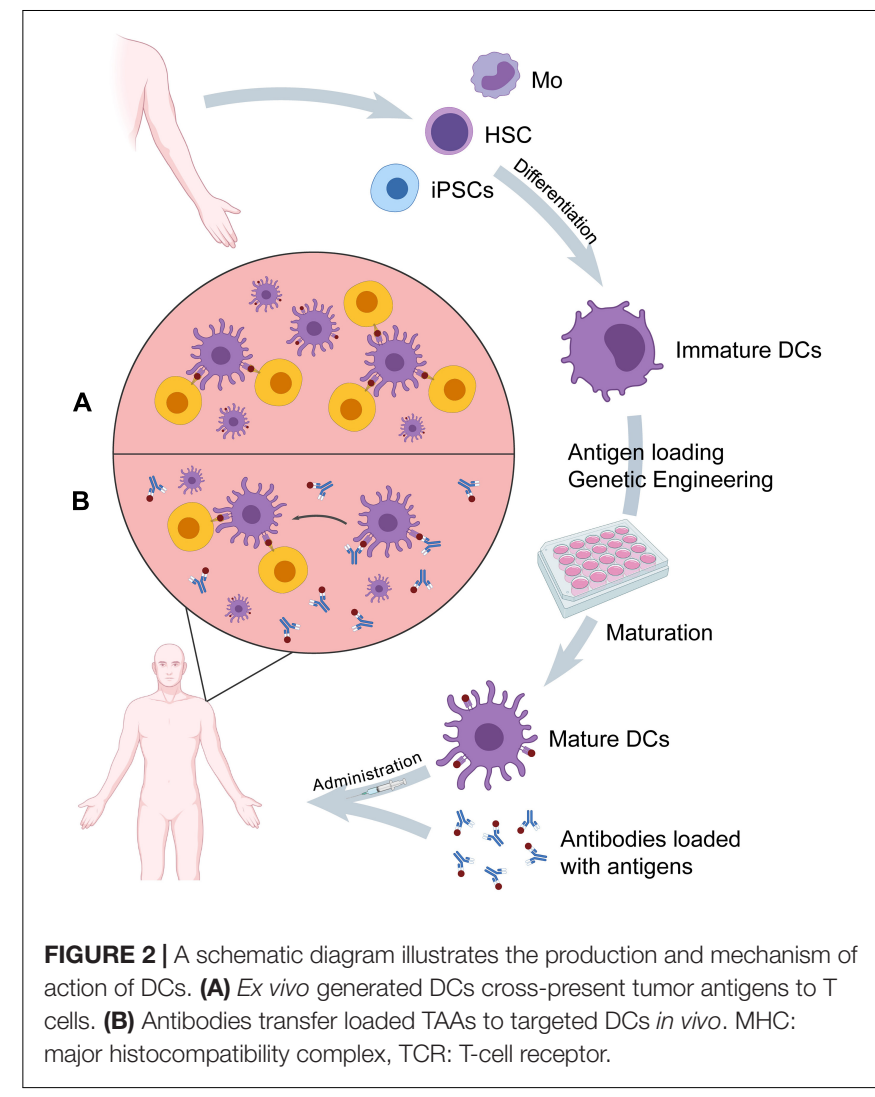

2003) or 2 days as in the case of FastDCs (Dauer et al., 2005). Other differentiation protocols include culturing peripheral blood mononuclear cells (PBMCs) with IFN- $\beta$ and either IL-3 or GM-CSF (Breckpot et al., 2005; Mazouz et al., 2005). However, the best maturation cocktail is yet to be defined. Immature DCs have less potential to induce effector immune cells as they do not produce stimulatory cytokines and express less levels of costimulatory molecules (Steinman and Swanson, 1995; Trombetta and Mellman, 2005). Different maturation cocktails were tested, such as TLR agonists, CD40 ligand (CD40L), and other cytokines to identify the ideal combination. Vopenkova et al. (2012) have compared various maturation signals' effect on MoDC functions and stated that lipopolysaccharide and IFN- $\gamma$ could give the highest response.

To date, the first and only FDA-approved DC vaccine (Provenge) consists of autologous APCs loaded with a recombinant fusion protein antigen, which is composed of GM-CSF and prostatic acid phosphatase (PAP). Provenge synthesis requires 4 days for maturation. It increased the median survival by 4 months in patients with metastatic castrationresistant prostate cancer (Anassi and Ndefo, 2011; Cheever and Higano, 2011). Accordingly, researchers have been developing strategies to acquire DCs with the ability to express TAAs through different techniques (Saxena and Bhardwaj, 2018; Perez and De Palma, 2019). One TAA-loading method is through pulsing DCs with certain epitopes to promote T-cell activity, which was tested in melanoma patients (Carreno et al., 2015). MUC1-pulsed DCs derived from PBMCs were tested in phase 
I/II clinical trials in patients with resected biliary and pancreatic cancers. MUC1-pulsed DCs increased the survival of 33\% of the vaccinated patients for up to 5 years (Lepisto et al., 2008). WT1-pulsed DCs in phase I clinical trials increased antigenspecific cytotoxic $\mathrm{T}$ cells in $20 \%$ of the treated patients with pancreatic cancer (Yanagisawa et al., 2018). Other TAA-loading strategies include whole-tumor-cell lysate-pulsed DCs (Li et al., 2010; Bauer et al., 2011), which express a broader range of tumor antigens suitable for personalized treatments, tumor cell fused with DC vaccines (Koido et al., 2013; Chen et al., 2015), or genetically modified DCs to express cancer-specific antigens (Miyazawa et al., 2011; Chen et al., 2013; Shindo et al., 2014; Maeda et al., 2015; Esprit et al., 2020).

TriMixDC is one type of mRNA-engineered DCs, which gained researchers' interest owing to their enhanced antitumor activity and feasibility compared to other mRNA-based vaccines (Anguille et al., 2014; Van Lint et al., 2015). The delivery of CD40L, CD70, and caTLR4 mRNA generates mature DCs in a one-step process without further incubation with other maturation cocktails for a certain period of time, which can exhaust the cells. Moreover, it eliminates the need to perform tumor biopsies followed by further purification in GMP settings for clinical use, as in the case of whole-tumor mRNA-based DC vaccines, which is laborious and time-consuming. Synthetic mRNA-based vaccines produce fewer side effects and show a higher possibility for optimization and large-scale generation than whole-tumor mRNA-based DC vaccines (Van Nuffel et al., 2010; Van Lint et al., 2014; Benteyn et al., 2015). Coelectroporation of TriMixDC with mRNA encoding a fusion of melanoma antigen and DC-LAMP, an approach named TriMixDC-MEL, stimulated antigen-specific $\mathrm{CD}^{+} \mathrm{T}$ and Th1 cells in vaccinated patients (Bonehill et al., 2009). In a phase II trial, TriMixDC-MEL combined with ipilimumab, a CTLA4 inhibitor, showed a $20 \%$ complete response and $\simeq 18 \%$ partial response in 39 patients with advanced melanoma (Wilgenhof et al., 2016). TriMixDC-MEL plus ipilimumab also resulted in $28 \%$ overall survival (OS) after 390 weeks of median follow-up and $18 \%$ progression-free survival (PFS) after $5+$ years in patients with stage III or IV melanoma (De Keersmaecker et al., 2020).

Additionally, Rosa et al. (2018) reprogrammed mouse and human fibroblasts into DCs named induced DCs (iDCs) by transduction of PU.1, Irf8, and Batf3 transcription factors. iDCs have $\mathrm{CDC1}$-like features and can prime antigen-specific $\mathrm{CD} 8^{+}$ T cells. Furthermore, BMDCs virally transduced with CCR7 gene generated CCR7-overexpressing mature-like DCs, which had a notable migration potential to draining lymph nodes (Okada et al., 2005).

Lastly, Squadrito et al. (2018) engineered DCs expressing chimeric receptors that are able to take up and process TAAs in situ. The introduction of the chimeric receptor allowed DCs to selectively take up tumor-derived extracellular vesicles, which can deliver TAAs to DCs. HER2-specific extracellular vesicle-internalizing receptor (EVIR)-expressing DCs showed a significant increase of antigen-specific cytotoxic T cells, resulting in an antitumor response (Squadrito et al., 2018). Blocking immunosuppressive signals is another promising approach in cancer vaccines. Researchers utilized small-interfering RNAs
(siRNAs) to knock down PD-L1 and PD-L2 genes in DCs. PD-L-silenced DCs increased T-cell expansion and IFN- $\gamma$ and IL-12 production (Hobo et al., 2010; van der Waart et al., 2015).

\section{iPSC-Derived DC Vaccines}

Genetically engineered DC vaccines expressing TAAs showed significant effectiveness against many cancer types (Ojima et al., 2007, 2008; Miyazawa et al., 2011). These strategies rely mostly on either primary DCs or ex vivo generated MoDCs, which require leukapheresis. Therefore, they are patient inconvenient, and their clinical application is restrained. Also, DCs exist as small populations in the blood (Jongbloed et al., 2010), and their number is further reduced in cancer patients (Beckebaum et al., 2004; Satthaporn et al., 2004; Poschke et al., 2012). Therefore, iPSCs are considered an unlimited and potential source to provide DCs (iPSC-DCs) in a suitable quantity.

Scientists have designed protocols to differentiate mouse and human iPSCs into DCs (Senju et al., 2009, 2011a; Li et al., 2014). For example, Silk et al. (2012) generated CD $141^{+} \mathrm{XCR} 1^{+} \mathrm{DCs}$ from iPSCs using a protocol that is free from animal-derived products, making them compatible with clinical applications. These iPSC-DCs were able to cross-present melan A antigen (melanoma antigen) and prime $\mathrm{CD}^{+} \mathrm{T}$ cells (Silk et al., 2012). To increase the yield of iPSC-DCs, researchers generated proliferating iPSC-derived myeloid cells (iPSC-pMLs) through the insertion of the $c-M Y C$ gene into iPSC-derived myeloid cells (iPSC-MLs). iPSC-pMLs were then differentiated into iPSCDCs through culturing in a medium containing IL-4 and GM-CSF for 3 days. iPSC-pMLs loaded with the OVA257264 peptide were able to prime $\mathrm{CD}^{+} \mathrm{T}$ cells in a syngeneic mouse model. Primed antigen-specific $\mathrm{CD}^{+} \mathrm{T}$ cells isolated from mouse spleen killed MO4 cells (OVA-expressing melanoma cells) in vitro. OVA257-264 peptide-loaded iPSC-DCs provided immunization for 3 months with no adverse effects (Zhang et al., 2015). To further increase iPSC-pML potency, iPSCpMLs were virally transduced with the IFN- $\alpha$ gene. In a bilateral melanoma transplantation model, local administration of IFN- $\alpha$-expressing iPSC-pMLs inhibited the tumor growth at treatment and remote sites, in addition to inhibition of lung metastasis (Tsuchiya et al., 2019).

In another study, researchers produced iPSC-DCs expressing carcinoembryonic antigen (CEA) (iPSDCs-CEA) and stimulated them using a maturation cocktail composed of recombinant human IL-6, IL-1 $\beta$, TNF- $\alpha$, and PGE2 for 2 days. iPSDCs-CEA was structurally similar to MoDCs, and the expression levels of CD80 and CD83 co-stimulatory molecules were comparable to those of MoDCs. Mature iPSDCs-CEA and MoDCs produced high levels of IFN- $\gamma$ and IL-12 with no significant difference in secretion levels between both cell types. Moreover, when iPSDCs-CEA were cultured with different cell lines expressing the HLA-A24 allele (MKN1, MKN45, HT29, and LCL-CEA652 cells), they were able to induce $\mathrm{CD}^{+} \mathrm{T}$ cells against MKN45, HT29, and LCL-CEA cells (CEA-expressing cells) but not MKN1 (lacking endogenous CEA). These results indicate that iPSDCs-CEA is able to stimulate human cytotoxic $\mathrm{T}$ cells with great specificity against gastrointestinal cancers expressing CEA (Kitadani et al., 2018). 
Iwamoto et al. (2014) generated iPSC-DCs and BMDCs. Mature iPSC-DCs expressed high levels of CD80, CD86, CD11c, and MHC II, similar to mature BMDCs. The migratory capacity of mature iPSC-DCs identified by the expression of CCR7 was analyzed and showed comparable results to those of mature BMDCs. In this study, using a gene-based vaccination strategy, researchers imparted both iPSC-DCs and BMDCs the ability to express hgp100 (human melanoma antigen) through transduction with a recombinant adenoviral vector. Tetramer and ${ }^{51} \mathrm{Cr}$-release assays revealed induction of cytotoxic $\mathrm{T}$ cells against B16 cells (melanoma cell line) in mice immunized with iPSC-DCs-hgp100 and BMDCs-hgp100. Additionally, iPSC-DCs-hgp100 administration significantly inhibited tumor growth in mice with subcutaneous B16 cells compared to phosphate-buffered saline, iPSC-DCs-LacZ, and BMDCs-LacZ as negative controls, suggesting that iPSC-DCs could be a promising approach in clinical practice as cancer vaccines (Iwamoto et al., 2014).

To enhance the antitumor potential of iPSC-DCs, Mashima et al. (2020) generated proliferating and GM-CSF-producing myeloid cells (GM-iPSC-pMLs) through the insertion of Csf2 and $c-M Y C$ genes into iPSC-MLs by a lentivirus vector. Similar to BMDCs, GM-iPSC-pMLs were able to stimulate cytotoxic T-cell proliferation. Additionally, when GM-iPSC-pMLs were pulsed with an OVA peptide, they were able to prime and stimulate antigen-specific cytotoxic $\mathrm{T}$ cells, indicating that GM-iPSCMLs had cross-presentation capacity like DCs. Interestingly, in a prophylactic experiment, administration of GM-iPSC-MLs loaded with the OVA peptide were able to inhibit tumor growth when taken 7 days before the mice were injected with subcutaneous MO4 cells.

\section{Stimulation of DCs in vivo}

Since ex vivo generated MoDCs have limited migration potential, it is crucial to focus on other research lines that involve systemic activation of in vivo DCs. Historically, researchers used immune activators such as bacterial products (Coley, 1910; Bernardes et al., 2010), TLR agonists (Adams, 2009; Chi et al., 2017), and bacillus Calmette-Guérin (BCG) (Kamat et al., 2017) to elicit antitumor activity. Immune activators have been found to induce antitumor immune response via DC activation (Kuhn et al., 2013) followed by CD8 ${ }^{+}$T-cell priming (Kuhn et al., 2015), and this approach is likely only functional when acting on DCs that already acquired tumor antigens, such as tumor-associated DCs. TGF- $\beta$ (Pu et al., 2018), 1-methyl-tryptophan (IDO inhibitor) (Li et al., 2010), and inhibiting IL-10 antibody (Marvel and Finn, 2014) have proven to act synergistically with DC vaccines in inhibiting pancreatic cancer growth. Intratumoral injection of cyclic diguanylate monophosphate (STING agonist) or cytosinephosphorothioate-guanine oligodeoxynucleotide (TLR agonist) enhanced T-cell activation and stimulated in situ DC maturation (Kawarada et al., 2001; Ohkuri et al., 2014). Imiquimod, a TLR7/TLR8 agonist, promotes pDC-mediated antitumor activity, and it is approved for the treatment of non-melanoma skin cancer (Drobits et al., 2012). Poly[I:C] and its derivatives have been used in different cancer vaccination studies and have shown significant outcomes (Martins et al., 2015).
In a melanoma mouse model, co-administration of Poly[I:C] and FLT3L enhanced $\mathrm{CD}_{103}{ }^{+} \mathrm{DC}$ expansion and $\mathrm{CD}^{+}$ T-cell recruitment at the tumor site and synergized PD-L1 antitumor activity (Salmon et al., 2016). The FDA granted an orphan drug designation to a rabies vaccine combined with poly[I:C], named YS-ON-001, for the treatment of pancreatic cancer and hepatocellular carcinoma (Goyvaerts and Breckpot, 2018). Importantly, in an ovarian cancer model, in situ co-administration of CD40 and TLR3 agonists has induced the polarization of tumor-infiltrating DCs into an immune stimulatory phenotype that was able to produce type I IFN and IL-12 p70, resulting in tumor remission (Scarlett et al., 2009). Interestingly, Penafuerte et al. developed FIST, a fusion protein of IL- 2 and the ectodomain of TGF- $\beta$ receptor II, to block immunosuppression activity of locally secreted TGF- $\beta$ and to activate IL-2 receptor-expressing lymphocytes. Administration of this fusokine recruited immune cells at the tumor site and stimulated IFN- $\gamma$ secretion (Penafuerte and Galipeau, 2012). Likewise, Van der Jeught et al. (2014) developed mRNA encoding IFN- $\beta$ and the ectodomain of TGF- $\beta$ receptor II fusokine, named $\mathrm{F} \beta 2$. When this mRNA was taken up by DCs and translated into the functioning protein, it stimulated DCs and induced antitumor immunity. Other strategies for intratumoral delivery of immunostimulatory signals such as TNF- $\alpha$, IL-12, and TGF$\beta$ and IL-10 neutralization are extensively reviewed elsewhere (Van der Jeught et al., 2015).

Cancer stem cells (CSCs) play a critical role in cancer progression and metastasis. CSCs are resistant to treatment since they possess antigens different from those present in differentiated tumor cells (Reya et al., 2001). Therefore, vaccination strategies relying on cells expressing stem cell antigens have gained researchers' interest (Dashti et al., 2016; Zhao et al., 2017). For instance, scientists have developed nextgeneration cancer vaccines that are more potent and targeted than conventional treatments. Mackiewicz et al. (1995) have developed a genetically engineered whole-tumor cell vaccine expressing hyper-IL-6 against melanoma, named AGI-101H, which has a melanoma stem cell-like phenotype (Mackiewicz and Mackiewicz, 2009). In clinical trials, this vaccine increased the survival of patients with advanced-stage melanoma (Mackiewicz et al., 2015, 2018). Genetically modified B16F10 (melanoma cell line) expressing hyper-IL-6 mixed with murine iPSCs increased DCs, natural killer (NK)-cell infiltration, and IFN- $\gamma$ and IL12 p70 production at the tumor site in a mouse model. The vaccines also inhibited the number of infiltrating Treg cells at TME and increased serum level of specific IgG against tumor cells, resulting in a significant reduction of tumor growth with a subsequent increase in the survival rate of the treated mice (Gabka-Buszek et al., 2020).

Targeting of DCs in vivo is another strategy that has shown promising results. DEC205 and CLEC9A are receptors that only DCs express. Antibodies targeting these receptors are efficient delivery molecules (Kreutz et al., 2013; Tullett et al., 2016). Mahnke et al. (2005) conjugated melanoma antigens with a DEC205 antibody. The conjugate selectively delivered the neoantigens to DCs, which stimulated $\mathrm{CD}^{+}$and $\mathrm{CD}^{+}{ }^{+}$-cell responses, leading to tumor regression (Mahnke et al., 2005). In a 
phase 1 clinical trial, anti-DEC-205 antibody-mediated delivery of NY-ESO-1 antigen was found to be safe and immunogenic, and it was tolerable as a combination therapy with immune checkpoint inhibitors (Dhodapkar et al., 2014). Conjugation of MUC1 antigen to oxidized mannan targeting mannose receptors (MRs) on DCs also stimulated DCs, and it is 1,000 times more efficient than reduced mannan conjugated to $\mathrm{MR}$ in MHC I presentation to cytotoxic T cells (Apostolopoulos et al., 2014). Researchers have used nanoparticles as vehicles in cancer immunotherapy to deliver synthetic long peptides (SLPs), mRNA, or viral vectors to overcome the drawbacks of protein-based vaccines, such as their limited cellular uptake and susceptibility to degradation by enzymes (Varypataki et al., 2016; Verbeke et al., 2017, 2019; Sharma et al., 2018).

Poly[I:C]-adjuvanted SLPs covalently bound to cationic dextran nanogels facilitated peptide internalization into DCs and stimulated cytotoxic T-cell response in vivo (Kordalivand et al., 2019). Similarly, SLPs loaded into cationic liposomes and adjuvanted with TLR ligand efficiently induced antigenspecific $\mathrm{T}$ cells in vivo (Varypataki et al., 2016). In the case of RNA-loaded nanoparticles, Kranz et al. (2016) used lipoplexes as carriers to protect RNA encoding neoantigens from ribonuclease degradation and efficiently deliver RNA to DCs. RNA lipoplexes were tested in clinical trials and found to induce IFN- $\alpha$ production and stimulate effector and memory T-cell activity (Kranz et al., 2016). Cubillos-Ruiz et al. (2012) designed a nanoparticle carrying a Dicer substrate, which mimics endogenous pre-miRNA. Uptake of this complex significantly induced miR-155 activity and reverted the tolerogenic potential of tumor-associated DCs. Subsequently, the complex abolished ovarian cancer progression in 33\% of the treated mice (CubillosRuiz et al., 2012). Lentiviral vectors attached to nanobodies is another strategy that has proven to have an efficient targeting potential to DCs both in vivo and in vitro (Goyvaerts et al., 2012). Combination therapy of plasmids carrying complementary DNA for FLT3L and adenoviral vector carrying IL-18 gene induced DC mobilization with higher CD86 expression, and achieved complete eradication of MCA205 fibrosarcoma in tumor-bearing mice (Saito et al., 2008).

\section{CONCLUSION}

In the past years, immunotherapy has proven to be an off-theshelf treatment approach in oncology due to its higher specificity and targeting capacity compared to traditional treatments, including, but not limited to, adoptive transfer of (NK) cells (Burger et al., 2019), macrophages (Klichinsky et al., 2020), T cells (June et al., 2018), and DCs.

Dendritic cells are a heterogeneous type of cells and play a vital role in maintaining immune homeostasis. They

\section{REFERENCES}

$\begin{aligned} & \text { Adams, S. (2009). Toll-like } \\ & \text { therapy. }\end{aligned}$ Immunotherapy 1,
$\begin{aligned} & 09.70 \\ & \text { Im }\end{aligned}$

are known as environmental sensors and are efficacious in phagocytizing non-self-antigens and presenting them on $\mathrm{MHC} \mathrm{I}$ and II to $\mathrm{CD}^{+}$and $\mathrm{CD}^{+}$naïve $\mathrm{T}$ cells. As a result of their plasticity, they are greatly affected by tumor-derived products. Thus, combinatorial strategies with other treatment modalities may act synergistically to inhibit DC tolerogenic polarization and improve their anticancer effect.

Dendritic cell vaccines are found to be feasible, safe, and immunogenic in clinical trials, making them an active area of research. For example, TriMixDC-MEL has shown promising results in inducing antitumor immunity, and it is being tested in clinical trials against melanoma. Moreover, strategies to deliver antibody-loaded neoantigens, activation signals, or nanobodies carrying SLPs or mRNA to induce DC activation in vivo have proven their efficacy in preclinical and clinical settings. On the other hand, some DC vaccine approaches have shown suboptimal antitumor activity, which could be due to improper DC generation protocol, maturation cocktail, or route of administration. To date, we do not know which DC subset, maturation cocktail, or antigen loading strategy is ideal for producing optimal efficacy. Notably, all DC subsets contribute to antitumor immunity. That's why a better understanding of DC biology could pave the way to developing multiplexed DC vaccines, leveraging the crosstalk among DC subpopulations.

Interestingly, the advancement in stem cell-based research provided a template for the development of personalized iPSCDC vaccines. Furthermore, targeting strategies of DCs in vivo to selectively deliver molecules to certain primary DC subsets offer a substitute for the laborious, time-consuming, and costly ex vivo generation, antigen loading, and maturation of DCs. Overall, taking into consideration the pros and cons of DC vaccines, it remains tempting to continue researching this field, aiming to provide innovative strategies to enhance their clinical efficacy.

\section{AUTHOR CONTRIBUTIONS}

AS, NQ, and YW contributed to the study conception and design. AS, HW, YL, MJ, and W-BO performed data collection and analysis. AS wrote the first draft of the manuscript. All authors read and approved the final manuscript.

\section{FUNDING}

This work was supported by grants from the Zhejiang Province Natural Science Foundation (no. LY17C120001) and the Enterprise Commissioned R\&D Project (grant no. 16040135-J).

Anassi, E., and Ndefo, U. A. (2011). Sipuleucel-T (provenge) injection: the first immunotherapy agent (vaccine) for hormone-refractory prostate cancer. PT 36, 197-202.

Anguille, S., Smits, E. L., Lion, E., van Tendeloo, V. F., and Berneman, Z. N. (2014). Clinical use of dendritic cells for cancer 
therapy. Lancet Oncol. 15, E257-E267. doi: 10.1016/S1470-2045(13) 70585-0

Anguille, S., Van de Velde, A. L., Smits, E. L., Van Tendeloo, V. F., Juliusson, G., Cools, N., et al. (2017). Dendritic cell vaccination as postremission treatment to prevent or delay relapse in acute myeloid leukemia. Blood 130, 1713-1721. doi: 10.1182/blood-2017-04-78 0155

Apostolopoulos, V., Pietersz, G. A., Tsibanis, A., Tsikkinis, A., Stojanovska, L., McKenzie, I. F., et al. (2014). Dendritic cell immunotherapy: clinical outcomes. Clin. Transl. Immunol. 3:e21. doi: 10.1038/cti.2014.14

Aspord, C., Leccia, M. T., Charles, J., and Plumas, J. (2013). Plasmacytoid dendritic cells support melanoma progression by promoting $\mathrm{Th} 2$ and regulatory immunity through OX40L and ICOSL. Cancer Immunol. Res. 1, 402-415. doi: 10.1158/2326-6066.CIR-13-0114-T

Bauer, C., Dauer, M., Saraj, S., Schnurr, M., Bauernfeind, F., Sterzik, A., et al. (2011). Dendritic cell-based vaccination of patients with advanced pancreatic carcinoma: results of a pilot study. Cancer Immunol. Immunother. 60, 10971107. doi: 10.1007/s00262-011-1023-5

Beckebaum, S., Zhang, X., Chen, X., Yu, Z., Frilling, A., Dworacki, G., et al. (2004). Increased levels of interleukin-10 in serum from patients with hepatocellular carcinoma correlate with profound numerical deficiencies and immature phenotype of circulating dendritic cell subsets. Clin. Cancer Res. 10, 7260-7269. doi: 10.1158/1078-0432.CCR-04-0872

Benteyn, D., Heirman, C., Bonehill, A., Thielemans, K., and Breckpot, K. (2015). mRNA-based dendritic cell vaccines. Exp. Rev. Vaccines 14, 161-176. doi: 10. 1586/14760584.2014.957684

Bernardes, N., Seruca, R., Chakrabarty, A. M., and Fialho, A. M. (2010). Microbialbased therapy of cancer: current progress and future prospects. Bioeng. Bugs 1, 178-190. doi: 10.4161/bbug.1.3.10903

Binnewies, M., Mujal, A. M., Pollack, J. L., Combes, A. J., Hardison, E. A., Barry, K. C., et al. (2019). Unleashing Type-2 Dendritic Cells to Drive Protective Antitumor CD4(+) T cell immunity. Cell 177, 556-571.e516. doi: 10.1016/j.cell. 2019.02.005

Bonehill, A., Tuyaerts, S., Van Nuffel, A. M., Heirman, C., Bos, T. J., Fostier, K., et al. (2008). Enhancing the T-cell stimulatory capacity of human dendritic cells by co-electroporation with CD40L, CD70 and constitutively active TLR4 encoding mRNA. Mol. Ther. 16, 1170-1180. doi: 10.1038/mt.2008.77

Bonehill, A., Van Nuffel, A. M., Corthals, J., Tuyaerts, S., Heirman, C., Francois, V., et al. (2009). Single-step antigen loading and activation of dendritic cells by mRNA electroporation for the purpose of therapeutic vaccination in melanoma patients. Clin. Cancer Res. 15, 3366-3375. doi: 10.1158/1078-0432.CCR-082982

Bottcher, J. P., Bonavita, E., Chakravarty, P., Blees, H., Cabeza-Cabrerizo, M., Sammicheli, S., et al. (2018). NK cells stimulate recruitment of cDC1 into the tumor microenvironment promoting cancer immune control. Cell 172, 1022-1037.e1014. doi: 10.1016/j.cell.2018.01.004

Breckpot, K., Corthals, J., Bonehill, A., Michiels, A., Tuyaerts, S., Aerts, C., et al. (2005). Dendritic cells differentiated in the presence of IFN- $\{$ beta $\}$ and IL-3 are potent inducers of an antigen-specific CD8+ T cell response. J. Leukoc Biol. 78, 898-908. doi: 10.1189/jlb.0105052

Burger, M. C., Zhang, C., Harter, P. N., Romanski, A., Strassheimer, F., Senft, C., et al. (2019). CAR-Engineered NK cells for the treatment of glioblastoma: turning innate effectors into precision tools for cancer immunotherapy. Front. Immunol. 10:2683. doi: 10.3389/fimmu.2019.02683

Butterfield, L. H., Ribas, A., Dissette, V. B., Amarnani, S. N., Vu, H. T., Oseguera, D., et al. (2003). Determinant spreading associated with clinical response in dendritic cell-based immunotherapy for malignant melanoma. Clin. Cancer Res. 9, 998-1008.

Cancel, J. C., Crozat, K., Dalod, M., and Mattiuz, R. (2019). Are conventional Type 1 dendritic cells critical for protective antitumor immunity and how? Front. Immunol. 10:9. doi: 10.3389/fimmu.2019.00009

Carreno, B. M., Magrini, V., Becker-Hapak, M., Kaabinejadian, S., Hundal, J., Petti, A. A., et al. (2015). Cancer immunotherapy. A dendritic cell vaccine increases the breadth and diversity of melanoma neoantigen-specific T cells. Science 348, 803-808. doi: 10.1126/science.aaa3828

Caruso, D. A., Orme, L. M., Neale, A. M., Radcliff, F. J., Amor, G. M., Maixner, W., et al. (2004). Results of a phase 1 study utilizing monocyte-derived dendritic cells pulsed with tumor RNA in children and young adults with brain cancer. Neuro Oncol. 6, 236-246. doi: 10.1215/S1152851703000668

Cheever, M. A., and Higano, C. S. (2011). PROVENGE (Sipuleucel-T) in prostate cancer: the first FDA-approved therapeutic cancer vaccine. Clin. Cancer Res. 17, 3520-3526. doi: 10.1158/1078-0432.CCR-10-3126

Chen, J., Guo, X. Z., Li, H. Y., Liu, X., Ren, L. N., Wang, D., et al. (2013). Generation of CTL responses against pancreatic cancer in vitro using dendritic cells co-transfected with MUC4 and survivin RNA. Vaccine 31, 4585-4590. doi: 10.1016/j.vaccine.2013.07.055

Chen, J., Guo, X. Z., Li, H. Y., Wang, D., and Shao, X. D. (2015). Comparison of cytotoxic $\mathrm{T}$ lymphocyte responses against pancreatic cancer induced by dendritic cells transfected with total tumor RNA and fusion hybrided with tumor cell. Exp. Biol. Med. (Maywood) 240, 1310-1318. doi: 10.1177/ 1535370215571884

Chi, H., Li, C., Zhao, F. S., Zhang, L., Ng, T. B., Jin, G., et al. (2017). Anti-tumor activity of toll-like receptor 7 agonists. Front. Pharmacol. 8:304. doi: 10.3389/ fphar.2017.00304

Chiang, M. C., Tullett, K. M., Lee, Y. S., Idris, A., Ding, Y., McDonald, K. J., et al. (2016). Differential uptake and cross-presentation of soluble and necrotic cell antigen by human DC subsets. Eur. J. Immunol. 46, 329-339. doi: 10.1002/eji. 201546023

Coley, W. B. (1910). The treatment of inoperable sarcoma by bacterial toxins (the mixed toxins of the streptococcus erysipelas and the Bacillus prodigiosus). Proc. R. So.c Med. 3, 1-48.

Collin, M., and Bigley, V. (2018). Human dendritic cell subsets: an update. Immunology 154, 3-20. doi: 10.1111/imm.12888

Conrad, C., Gregorio, J., Wang, Y. H., Ito, T., Meller, S., Hanabuchi, S., et al. (2012). Plasmacytoid dendritic cells promote immunosuppression in ovarian cancer via ICOS costimulation of Foxp3(+) T-regulatory cells. Cancer Res. 72, 5240-5249. doi: 10.1158/0008-5472.CAN-12-2271

Cubillos-Ruiz, J. R., Baird, J. R., Tesone, A. J., Rutkowski, M. R., Scarlett, U. K., Camposeco-Jacobs, A. L., et al. (2012). Reprogramming tumor-associated dendritic cells in vivo using miRNA mimetics triggers protective immunity against ovarian cancer. Cancer Res. 72, 1683-1693. doi: 10.1158/0008-5472. CAN-11-3160

Cubillos-Ruiz, J. R., Silberman, P. C., Rutkowski, M. R., Chopra, S., Perales-Puchalt, A., Song, M., et al. (2015). ER stress sensor XBP1 controls anti-tumor immunity by disrupting dendritic cell homeostasis. Cell 161, 1527-1538. doi: 10.1016/j. cell.2015.05.025

Dashti, A., Ebrahimi, M., Hadjati, J., Memarnejadian, A., and Moazzeni, S. M. (2016). Dendritic cell based immunotherapy using tumor stem cells mediates potent antitumor immune responses. Cancer Lett. 374, 175-185. doi: 10.1016/j. canlet.2016.01.021

Dauer, M., Obermaier, B., Herten, J., Haerle, C., Pohl, K., Rothenfusser, S., et al. (2003). Mature dendritic cells derived from human monocytes within 48 hours: a novel strategy for dendritic cell differentiation from blood precursors. J. Immunol. 170, 4069-4076. doi: 10.4049/jimmunol.170.8.4069

Dauer, M., Schad, K., Herten, J., Junkmann, J., Bauer, C., Kiefl, R., et al. (2005). FastDC derived from human monocytes within $48 \mathrm{~h}$ effectively prime tumor antigen-specific cytotoxic T cells. J. Immunol. Methods 302, 145-155. doi: 10. 1016/j.jim.2005.05.010

De Keersmaecker, B., Claerhout, S., Carrasco, J., Bar, I., Corthals, J., Wilgenhof, S., et al. (2020). TriMix and tumor antigen mRNA electroporated dendritic cell vaccination plus ipilimumab: link between T-cell activation and clinical responses in advanced melanoma. J. Immunother. Cancer 8:e000329. doi: 10. 1136/jitc-2019-000329

de Mingo Pulido, A., Gardner, A., Hiebler, S., Soliman, H., Rugo, H. S., Krummel, M. F., et al. (2018). TIM-3 regulates CD103(+) dendritic cell function and response to chemotherapy in breast cancer. Cancer Cell 33, 60-74.e66. doi: 10.1016/j.ccell.2017.11.019

Depil, S., Duchateau, P., Grupp, S. A., Mufti, G., and Poirot, L. (2020). 'Off-theshelf’ allogeneic CAR T cells: development and challenges. Nat. Rev. Drug Discov. 19, 185-199. doi: 10.1038/s41573-019-0051-2

Dhodapkar, M. V., Sznol, M., Zhao, B., Wang, D., Carvajal, R. D., Keohan, M. L., et al. (2014). Induction of antigen-specific immunity with a vaccine targeting NY-ESO-1 to the dendritic cell receptor DEC-205. Sci. Transl. Med. 6:232ra251. doi: $10.1126 /$ scitranslmed.3008068 
Diken, M., Kreiter, S., Selmi, A., Britten, C. M., Huber, C., Tureci, O., et al. (2011). Selective uptake of naked vaccine RNA by dendritic cells is driven by macropinocytosis and abrogated upon DC maturation. Gene Ther. 18, 702-708. doi: $10.1038 /$ gt.2011.17

Dragicevic, A., Dzopalic, T., Vasilijic, S., Vucevic, D., Tomic, S., Bozic, B., et al. (2012). Signaling through Toll-like receptor 3 and Dectin-1 potentiates the capability of human monocyte-derived dendritic cells to promote T-helper 1 and T-helper 17 immune responses. Cytotherapy 14, 598-607. doi: 10.3109/ 14653249.2012.667873

Drobits, B., Holcmann, M., Amberg, N., Swiecki, M., Grundtner, R., Hammer, M., et al. (2012). Imiquimod clears tumors in mice independent of adaptive immunity by converting pDCs into tumor-killing effector cells. J. Clin. Invest. 122, 575-585. doi: 10.1172/JCI61034

Dullaers, M., Van Meirvenne, S., Heirman, C., Straetman, L., Bonehill, A., Aerts, J. L., et al. (2006). Induction of effective therapeutic antitumor immunity by direct in vivo administration of lentiviral vectors. Gene Ther. 13, 630-640. doi: 10.1038/sj.gt.3302697

Eisenbarth, S. C. (2019). Dendritic cell subsets in T cell programming: location dictates function. Nat. Rev. Immunol. 19, 89-103. doi: 10.1038/s41577-0180088- 1

Esprit, A., de Mey, W., Bahadur Shahi, R., Thielemans, K., Franceschini, L., and Breckpot, K. (2020). Neo-Antigen mRNA Vaccines. Vaccines (Basel) 8:776. doi: $10.3390 /$ vaccines 8040776

Fry, T. J., Shah, N. N., Orentas, R. J., Stetler-Stevenson, M., Yuan, C. M., Ramakrishna, S., et al. (2018). CD22-targeted CAR T cells induce remission in B-ALL that is naive or resistant to CD19-targeted CAR immunotherapy. Nat. Med. 24, 20-28. doi: 10.1038/nm.4441

Gabka-Buszek, A., Kwiatkowska-Borowczyk, E., Jankowski, J., Kozlowska, A. K., and Mackiewicz, A. (2020). Novel genetic melanoma vaccines based on induced pluripotent stem cells or melanosphere-derived stem-like cells display high efficacy in a murine tumor rejection model. Vaccines (Basel) 8:147. doi: 10.3390/ vaccines 8020147

Geissmann, F., Manz, M. G., Jung, S., Sieweke, M. H., Merad, M., and Ley, K. (2010). Development of monocytes, macrophages, and dendritic cells. Science 327, 656-661. doi: 10.1126/science.1178331

Gottfried, E., Kunz-Schughart, L. A., Ebner, S., Mueller-Klieser, W., Hoves, S., Andreesen, R., et al. (2006). Tumor-derived lactic acid modulates dendritic cell activation and antigen expression. Blood 107, 2013-2021. doi: 10.1182/blood2005-05- 1795

Goyvaerts, C., and Breckpot, K. (2018). The journey of in vivo virus engineered dendritic cells from bench to bedside: a bumpy road. Front. Immunol. 9:2052. doi: 10.3389/fimmu.2018.02052

Goyvaerts, C., De Groeve, K., Dingemans, J., Van Lint, S., Robays, L., Heirman, C., et al. (2012). Development of the Nanobody display technology to target lentiviral vectors to antigen-presenting cells. Gene Ther. 19, 1133-1140. doi: 10.1038/gt.2011.206

Goyvaerts, C., Kurt de, G., Van Lint, S., Heirman, C., Van Ginderachter, J. A., De Baetselier, P., et al. (2014). Immunogenicity of targeted lentivectors. Oncotarget 5, 704-715. doi: 10.18632/oncotarget. 1680

Grajales-Reyes, G. E., Iwata, A., Albring, J., Wu, X., Tussiwand, R., Kc, W., et al. (2015). Batf3 maintains autoactivation of Irf8 for commitment of a CD8alpha(+) conventional DC clonogenic progenitor. Nat. Immunol. 16, 708717. doi: $10.1038 /$ ni.3197

Guilliams, M., Dutertre, C. A., Scott, C. L., McGovern, N., Sichien, D., Chakarov, S., et al. (2016). Unsupervised high-dimensional analysis aligns dendritic cells across tissues and species. Immunity 45, 669-684. doi: 10.1016/j.immuni.2016. 08.015

Hanahan, D., and Weinberg, R. A. (2011). Hallmarks of cancer: the next generation. Cell 144, 646-674. doi: 10.1016/j.cell.2011.02.013

Helft, J., Bottcher, J., Chakravarty, P., Zelenay, S., Huotari, J., Schraml, B. U., et al. (2015). GM-CSF mouse bone marrow cultures comprise a heterogeneous population of $\mathrm{CD} 11 \mathrm{c}(+) \mathrm{MHCII}(+)$ macrophages and dendritic cells. Immunity 42, 1197-1211. doi: 10.1016/j.immuni.2015. 05.018

Helmy, K. Y., Patel, S. A., Nahas, G. R., and Rameshwar, P. (2013). Cancer immunotherapy: accomplishments to date and future promise. Ther. Deliv. 4, 1307-1320. doi: $10.4155 /$ tde. 13.88
Herber, D. L., Cao, W., Nefedova, Y., Novitskiy, S. V., Nagaraj, S., Tyurin, V. A., et al. (2010). Lipid accumulation and dendritic cell dysfunction in cancer. Nat. Med. 16, 880-886. doi: 10.1038/nm.2172

Hildner, K., Edelson, B. T., Purtha, W. E., Diamond, M., Matsushita, H., Kohyama, M., et al. (2008). Batf3 deficiency reveals a critical role for CD8alpha+ dendritic cells in cytotoxic T cell immunity. Science 322, 1097-1100. doi: 10.1126/science. 1164206

Hobo, W., Maas, F., Adisty, N., de Witte, T., Schaap, N., van der Voort, R., et al. (2010). siRNA silencing of PD-L1 and PD-L2 on dendritic cells augments expansion and function of minor histocompatibility antigen-specific CD8+ $\mathrm{T}$ cells. Blood 116, 4501-4511. doi: 10.1182/blood-2010-04-278739

Ito, T., Yang, M., Wang, Y. H., Lande, R., Gregorio, J., Perng, O. A., et al. (2007). Plasmacytoid dendritic cells prime IL-10-producing T regulatory cells by inducible costimulator ligand. J. Exp. Med. 204, 105-115. doi: 10.1084/jem. 20061660

Iwamoto, H., Ojima, T., Hayata, K., Katsuda, M., Miyazawa, M., Iida, T., et al. (2014). Antitumor immune response of dendritic cells (DCs) expressing tumorassociated antigens derived from induced pluripotent stem cells: in comparison to bone marrow-derived DCs. Int. J. Cancer 134, 332-341. doi: 10.1002/ijc. 28367

Jansen, Y., Kruse, V., Corthals, J., Schats, K., van Dam, P. J., Seremet, T., et al. (2020). A randomized controlled phase II clinical trial on mRNA electroporated autologous monocyte-derived dendritic cells (TriMixDC-MEL) as adjuvant treatment for stage III/IV melanoma patients who are disease-free following the resection of macrometastases. Cancer Immunol. Immunother. 69, 2589-2598. doi: 10.1007/s00262-020-02618-4

Jochems, C., and Schlom, J. (2011). Tumor-infiltrating immune cells and prognosis: the potential link between conventional cancer therapy and immunity. Exp. Biol. Med. (Maywood) 236, 567-579. doi: 10.1258/ebm.2011.011007

Joffre, O. P., Segura, E., Savina, A., and Amigorena, S. (2012). Cross-presentation by dendritic cells. Nat. Rev. Immunol. 12, 557-569. doi: 10.1038/nri3254

Jongbloed, S. L., Kassianos, A. J., McDonald, K. J., Clark, G. J., Ju, X., Angel, C. E., et al. (2010). Human CD141+ (BDCA-3)+ dendritic cells (DCs) represent a unique myeloid DC subset that cross-presents necrotic cell antigens. J. Exp. Med. 207, 1247-1260. doi: 10.1084/jem.20092140

June, C. H., O’Connor, R. S., Kawalekar, O. U., Ghassemi, S., and Milone, M. C. (2018). CAR T cell immunotherapy for human cancer. Science 359, 1361-1365. doi: 10.1126/science.aar6711

Kaisho, T., and Akira, S. (2003). Regulation of dendritic cell function through Tolllike receptors. Curr. Mol. Med. 3, 373-385. doi: 10.2174/1566524033479726

Kamat, A. M., Bellmunt, J., Galsky, M. D., Konety, B. R., Lamm, D. L., Langham, D., et al. (2017). Society for immunotherapy of cancer consensus statement on immunotherapy for the treatment of bladder carcinoma. J. Immunother. Cancer 5:68. doi: 10.1186/s40425-017-0271-0

Kawarada, Y., Ganss, R., Garbi, N., Sacher, T., Arnold, B., and Hammerling, G. J. (2001). NK- and CD8(+) T cell-mediated eradication of established tumors by peritumoral injection of CpG-containing oligodeoxynucleotides. J. Immunol. 167, 5247-5253. doi: 10.4049/jimmunol.167.9.5247

Kirkling, M. E., Cytlak, U., Lau, C. M., Lewis, K. L., Resteu, A., KhodadadiJamayran, A., et al. (2018). Notch signaling facilitates in vitro generation of cross-presenting classical dendritic cells. Cell Rep. 23, 3658-3672.e6. doi: 10. 1016/j.celrep.2018.05.068

Kitadani, J., Ojima, T., Iwamoto, H., Tabata, H., Nakamori, M., Nakamura, M., et al. (2018). Cancer vaccine therapy using carcinoembryonic antigen - expressing dendritic cells generated from induced pluripotent stem cells. Sci. Rep. 8:4569. doi: 10.1038/s41598-018-23120-Z

Kitamura, H., Ohno, Y., Toyoshima, Y., Ohtake, J., Homma, S., Kawamura, H., et al. (2017). Interleukin-6/STAT3 signaling as a promising target to improve the efficacy of cancer immunotherapy. Cancer Sci. 108, 1947-1952. doi: 10.1111/ cas. 13332

Klichinsky, M., Ruella, M., Shestova, O., Lu, X. M., Best, A., Zeeman, M., et al. (2020). Human chimeric antigen receptor macrophages for cancer immunotherapy. Nat. Biotechnol. 38, 947-953. doi: 10.1038/s41587-0200462-y

Koido, S., Homma, S., Okamoto, M., Namiki, Y., Takakura, K., Uchiyama, K., et al. (2013). Fusions between dendritic cells and whole tumor cells as anticancer vaccines. Oncoimmunology 2:e24437. doi: 10.4161/onci.24437 
Kordalivand, N., Tondini, E., Lau, C. Y. J., Vermonden, T., Mastrobattista, E., Hennink, W. E., et al. (2019). Cationic synthetic long peptides-loaded nanogels: an efficient therapeutic vaccine formulation for induction of T-cell responses. $J$ Control Release 315, 114-125. doi: 10.1016/j.jconrel.2019.10.048

Kranz, L. M., Diken, M., Haas, H., Kreiter, S., Loquai, C., Reuter, K. C., et al. (2016). Systemic RNA delivery to dendritic cells exploits antiviral defence for cancer immunotherapy. Nature 534, 396-401. doi: 10.1038/nature18300

Kreutz, M., Tacken, P. J., and Figdor, C. G. (2013). Targeting dendritic cells-why bother? Blood 121, 2836-2844. doi: 10.1182/blood-2012-09-452078

Kuhn, S., Hyde, E. J., Yang, J., Rich, F. J., Harper, J. L., Kirman, J. R., et al. (2013). Increased numbers of monocyte-derived dendritic cells during successful tumor immunotherapy with immune-activating agents. J. Immunol. 191, 1984-1992. doi: 10.4049/jimmunol.1301135

Kuhn, S., Yang, J., and Ronchese, F. (2015). Monocyte-derived dendritic cells are essential for $\mathrm{CD} 8(+) \mathrm{T}$ cell activation and antitumor responses after local immunotherapy. Front. Immunol. 6:584. doi: 10.3389/fimmu.2015.00584

Laoui, D., Keirsse, J., Morias, Y., Van Overmeire, E., Geeraerts, X., Elkrim, Y., et al. (2016). The tumour microenvironment harbours ontogenically distinct dendritic cell populations with opposing effects on tumour immunity. Nat. Commun. 7:13720. doi: 10.1038/ncomms 13720

Le, D. T., Wang-Gillam, A., Picozzi, V., Greten, T. F., Crocenzi, T., Springett, G., et al. (2015). Safety and survival with GVAX pancreas prime and Listeria Monocytogenes-expressing mesothelin (CRS-207) boost vaccines for metastatic pancreatic cancer. J. Clin. Oncol. 33, 1325-1333. doi: 10.1200/JCO.2014.57. 4244

Leal Rojas, I. M., Mok, W. H., Pearson, F. E., Minoda, Y., Kenna, T. J., Barnard, R. T., et al. (2017). Human blood CD1c(+) dendritic cells promote Th1 and Th17 effector function in memory CD4(+) T Cells. Front. Immunol. 8:971. doi: 10.3389/fimmu.2017.00971

Lee, J., Breton, G., Aljoufi, A., Zhou, Y. J., Puhr, S., Nussenzweig, M. C., et al. (2015). Clonal analysis of human dendritic cell progenitor using a stromal cell culture. J. Immunol. Methods 425, 21-26. doi: 10.1016/j.jim.2015.06.004

Lepisto, A. J., Aj, M., Zeh, H., Lee, K., Bartlett, D., McKolanis, J. R., et al. (2008). A phase I/II study of a MUC1 peptide pulsed autologous dendritic cell vaccine as adjuvant therapy in patients with resected pancreatic and biliary tumors. Cancer Ther. 6, 955-964.

Li, Y., Liu, M., and Yang, S. T. (2014). Dendritic cells derived from pluripotent stem cells: potential of large scale production. World J. Stem Cells 6, 1-10. doi: $10.4252 /$ wjsc.v6.i1.1

Li, Y., Xu, J., Zou, H., and Wang, C. (2010). 1-MT enhances potency of tumor cell lysate-pulsed dendritic cells against pancreatic adenocarcinoma by downregulating the percentage of Tregs. J. Huazhong Univ. Sci. Technol. Med. Sci. 30, 344-348. doi: 10.1007/s11596-010-0354-3

Lombardi, V. C., Khaiboullina, S. F., and Rizvanov, A. A. (2015). Plasmacytoid dendritic cells, a role in neoplastic prevention and progression. Eur. J. Clin. Invest. 45(Suppl 1), 1-8. doi: 10.1111/eci.12363

Mackiewicz, A., Gorny, A., Laciak, M., Malicki, J., Murawa, P., Nowak, J., et al. (1995). Gene therapy of human melanoma. Immunization of patients with autologous tumor cells admixed with allogeneic melanoma cells secreting interleukin 6 and soluble interleukin 6 receptor. Hum. Gene Ther. 6, 805-811. doi: 10.1089/hum.1995.6.6-805

Mackiewicz, J., Burzykowski, T., Izycki, D., and Mackiewicz, A. (2018). Reinduction using whole cell melanoma vaccine genetically modified to melanoma stem cells-like beyond recurrence extends long term survival of high risk resected patients - updated results. J. Immunother. Cancer 6:134. doi: 10.1186/ s40425-018-0456-1

Mackiewicz, J., Karczewska-Dzionk, A., Laciak, M., Kapcinska, M., Wiznerowicz, M., Burzykowski, T., et al. (2015). Whole cell therapeutic vaccine modified with hyper-IL6 for combinational treatment of nonresected advanced melanoma. Medicine (Baltimore) 94:e853. doi: 10.1097/MD.0000000000000853

Mackiewicz, J., and Mackiewicz, A. (2009). Design of clinical trials for therapeutic cancer vaccines development. Eur. J. Pharmacol. 625, 84-89. doi: 10.1016/j. ejphar.2009.09.069

Maeda, Y., Yoshimura, K., Matsui, H., Shindo, Y., Tamesa, T., Tokumitsu, Y., et al. (2015). Dendritic cells transfected with heat-shock protein 70 messenger RNA for patients with hepatitis $\mathrm{C}$ virus-related hepatocellular carcinoma: a phase 1 dose escalation clinical trial. Cancer Immunol. Immunother. 64, 1047-1056. doi: 10.1007/s00262-015-1709-1
Mahnke, K., Qian, Y., Fondel, S., Brueck, J., Becker, C., and Enk, A. H. (2005). Targeting of antigens to activated dendritic cells in vivo cures metastatic melanoma in mice. Cancer Res. 65, 7007-7012. doi: 10.1158/0008-5472.CAN05-0938

Malvehy, J., Samoylenko, I., Schadendorf, D., Gutzmer, R., Grob, J. J., Sacco, J. J., et al. (2021). Talimogene laherparepvec upregulates immune-cell populations in non-injected lesions: findings from a phase II, multicenter, open-label study in patients with stage IIIB-IVM1c melanoma. J. Immunother. Cancer 9:e001621. doi: 10.1136/jitc-2020-001621

Martinez-Lopez, M., Iborra, S., Conde-Garrosa, R., and Sancho, D. (2015). Batf3dependent $\mathrm{CD} 103+$ dendritic cells are major producers of IL-12 that drive local Th1 immunity against Leishmania major infection in mice. Eur. J. Immunol. 45, 119-129. doi: 10.1002/eji.201444651

Martin-Gayo, E., Gonzalez-Garcia, S., Garcia-Leon, M. J., Murcia-Ceballos, A., Alcain, J., Garcia-Peydro, M., et al. (2017). Spatially restricted JAG1-Notch signaling in human thymus provides suitable DC developmental niches. J. Exp. Med. 214, 3361-3379. doi: 10.1084/jem.20161564

Martins, K. A., Bavari, S., and Salazar, A. M. (2015). Vaccine adjuvant uses of polyIC and derivatives. Exp. Rev. Vaccines 14, 447-459. doi: 10.1586/14760584.2015. 966085

Marvel, D. M., and Finn, O. J. (2014). Global inhibition of DC priming capacity in the spleen of self-antigen vaccinated mice requires IL-10. Front. Immunol. 5:59. doi: 10.3389/fimmu.2014.00059

Mashima, H., Zhang, R., Kobayashi, T., Hagiya, Y., Tsukamoto, H., Liu, T., et al. (2020). Generation of GM-CSF-producing antigen-presenting cells that induce a cytotoxic T cell-mediated antitumor response. Oncoimmunology 9:1814620. doi: 10.1080/2162402X.2020.1814620

Mastelic-Gavillet, B., Balint, K., Boudousquie, C., Gannon, P. O., and Kandalaft, L. E. (2019). Personalized dendritic cell vaccines-recent breakthroughs and encouraging clinical results. Front. Immunol. 10:766. doi: 10.3389/fimmu.2019. 00766

Matsui, T., Connolly, J. E., Michnevitz, M., Chaussabel, D., Yu, C. I., Glaser, C., et al. (2009). CD2 distinguishes two subsets of human plasmacytoid dendritic cells with distinct phenotype and functions. J. Immunol. 182, 6815-6823. doi: 10.4049/jimmunol.0802008

Maurya, N., Gujar, R., Gupta, M., Yadav, V., Verma, S., and Sen, P. (2014). Immunoregulation of dendritic cells by the receptor $\mathrm{T}$ cell $\mathrm{Ig}$ and mucin protein-3 via Bruton's tyrosine kinase and c-Src. J. Immunol. 193, 3417-3425. doi: 10.4049/jimmunol.1400395

Mazouz, N., Detournay, O., Buelens, C., Renneson, J., Trakatelli, M., Lambermont, M., et al. (2005). Immunostimulatory properties of human dendritic cells generated using IFN-beta associated either with IL-3 or GM-CSF. Cancer Immunol. Immunother. 54, 1010-1017. doi: 10.1007/s00262-0050664-7

Michiels, A., Breckpot, K., Corthals, J., Tuyaerts, S., Bonehill, A., Heirman, C., et al. (2006). Induction of antigen-specific CD8+ cytotoxic T cells by dendritic cells co-electroporated with a dsRNA analogue and tumor antigen mRNA. Gene Ther. 13, 1027-1036. doi: 10.1038/sj.gt.3302750

Michielsen, A. J., Hogan, A. E., Marry, J., Tosetto, M., Cox, F., Hyland, J. M., et al. (2011). Tumour tissue microenvironment can inhibit dendritic cell maturation in colorectal cancer. PLoS One 6:e27944. doi: 10.1371/journal.pone.002 7944

Mitchell, D., Chintala, S., and Dey, M. (2018). Plasmacytoid dendritic cell in immunity and cancer. J. Neuroimmunol. 322, 63-73. doi: 10.1016/j.jneuroim. 2018.06.012

Mittal, D., Gubin, M. M., Schreiber, R. D., and Smyth, M. J. (2014). New insights into cancer immunoediting and its three component phases-elimination, equilibrium and escape. Curr. Opin. Immunol. 27, 16-25. doi: 10.1016/j.coi. 2014.01.004

Miyazawa, M., Iwahashi, M., Ojima, T., Katsuda, M., Nakamura, M., Nakamori, M., et al. (2011). Dendritic cells adenovirally-transduced with full-length mesothelin cDNA elicit mesothelin-specific cytotoxicity against pancreatic cancer cell lines in vitro. Cancer Lett. 305, 32-39. doi: 10.1016/j.canlet.2011. 02.013

Mohty, M., Vialle-Castellano, A., Nunes, J. A., Isnardon, D., Olive, D., and Gaugler, B. (2003). IFN-alpha skews monocyte differentiation into Toll-like receptor 7expressing dendritic cells with potent functional activities. J. Immunol. 171, 3385-3393. doi: 10.4049/jimmunol.171.7.3385 
Morse, M. A., Coleman, R. E., Akabani, G., Niehaus, N., Coleman, D., and Lyerly, H. K. (1999). Migration of human dendritic cells after injection in patients with metastatic malignancies. Cancer Res. 59, 56-58.

Morse, M. A., Nair, S. K., Mosca, P. J., Hobeika, A. C., Clay, T. M., Deng, Y., et al. (2003). Immunotherapy with autologous, human dendritic cells transfected with carcinoembryonic antigen mRNA. Cancer Invest. 21, 341-349. doi: 10. $1081 /$ cnv- 120018224

Morse, M. A., Niedzwiecki, D., Marshall, J. L., Garrett, C., Chang, D. Z., Aklilu, M., et al. (2013). A randomized phase II study of immunization with dendritic cells modified with poxvectors encoding CEA and MUC1 compared with the same poxvectors plus GM-CSF for resected metastatic colorectal cancer. Ann. Surg. 258, 879-886. doi: 10.1097/SLA.0b013e318292919e

Naik, S. H., Sathe, P., Park, H. Y., Metcalf, D., Proietto, A. I., Dakic, A., et al. (2007). Development of plasmacytoid and conventional dendritic cell subtypes from single precursor cells derived in vitro and in vivo. Nat. Immunol. 8, 1217-1226. doi: $10.1038 /$ ni1522

Nestle, F. O., Alijagic, S., Gilliet, M., Sun, Y., Grabbe, S., Dummer, R., et al. (1998). Vaccination of melanoma patients with peptide- or tumor lysate-pulsed dendritic cells. Nat. Med. 4, 328-332. doi: 10.1038/nm0398-328

Ohkuri, T., Ghosh, A., Kosaka, A., Zhu, J., Ikeura, M., David, M., et al. (2014). STING contributes to antiglioma immunity via triggering type I IFN signals in the tumor microenvironment. Cancer Immunol. Res. 2, 1199-1208. doi: 10.1158/2326-6066.CIR-14-0099

Ojima, T., Iwahashi, M., Nakamura, M., Matsuda, K., Nakamori, M., Ueda, K., et al. (2007). Successful cancer vaccine therapy for carcinoembryonic antigen (CEA)expressing colon cancer using genetically modified dendritic cells that express CEA and T helper-type 1 cytokines in CEA transgenic mice. Int. J. Cancer 120, 585-593. doi: 10.1002/ijc.22298

Ojima, T., Iwahashi, M., Nakamura, M., Matsuda, K., Nakamori, M., Ueda, K., et al. (2008). Streptococcal preparation OK-432 promotes the capacity of dendritic cells (DCs) to prime carcinoembryonic antigen (CEA)-specific cytotoxic $\mathrm{T}$ lymphocyte responses induced with genetically modified DCs that express CEA. Int. J. Oncol. 32, 459-466. doi: 10.3892/ijo.32.2.459

Okada, N., Mori, N., Koretomo, R., Okada, Y., Nakayama, T., Yoshie, O., et al. (2005). Augmentation of the migratory ability of DC-based vaccine into regional lymph nodes by efficient CCR7 gene transduction. Gene Ther. 12, 129-139. doi: 10.1038/sj.gt.3302358

O’Keeffe, M., Mok, W. H., and Radford, K. J. (2015). Human dendritic cell subsets and function in health and disease. Cell Mol. Life Sci. 72, 4309-4325. doi: 10.1007/s00018-015-2005-0

Palucka, K., Banchereau, J., and Mellman, I. (2010). Designing vaccines based on biology of human dendritic cell subsets. Immunity 33, 464-478. doi: 10.1016/j. immuni.2010.10.007

Patente, T. A., Pinho, M. P., Oliveira, A. A., Evangelista, G. C. M., Bergami-Santos, P. C., and Barbuto, J. A. M. (2018). Human dendritic cells: their heterogeneity and clinical application potential in cancer immunotherapy. Front. Immunol. 9:3176. doi: 10.3389/fimmu.2018.03176

Penafuerte, C., and Galipeau, J. (2012). FIST, a sword and shield fusokine for cancer immunotherapy. Oncoimmunology 1, 224-226. doi: 10.4161/onci.1.2.18458

Perez, C. R., and De Palma, M. (2019). Engineering dendritic cell vaccines to improve cancer immunotherapy. Nat. Commun. 10:5408. doi: 10.1038/s41467019-13368-y

Poschke, I., Mao, Y., Adamson, L., Salazar-Onfray, F., Masucci, G., and Kiessling, R. (2012). Myeloid-derived suppressor cells impair the quality of dendritic cell vaccines. Cancer Immunol. Immunother. 61, 827-838. doi: 10.1007/s00262011-1143-y

Poulin, L. F., Reyal, Y., Uronen-Hansson, H., Schraml, B. U., Sancho, D., Murphy, K. M., et al. (2012). DNGR-1 is a specific and universal marker of mouse and human Batf3-dependent dendritic cells in lymphoid and nonlymphoid tissues. Blood 119, 6052-6062. doi: 10.1182/blood-2012-01-406967

Poulin, L. F., Salio, M., Griessinger, E., Anjos-Afonso, F., Craciun, L., Chen, J.L., et al. (2010). Characterization of human DNGR-1+ BDCA3+ leukocytes as putative equivalents of mouse CD8alpha+ dendritic cells. J. Exp. Med. 207, 1261-1271.

Prue, R. L., Vari, F., Radford, K. J., Tong, H., Hardy, M. Y., D’Rozario, R., et al. (2015). A phase I clinical trial of CD1c (BDCA-1)+ dendritic cells pulsed with HLA-A*0201 peptides for immunotherapy of metastatic hormone refractory prostate cancer. J. Immunother. 38, 71-76. doi: 10.1097/CJI.0000000000000063
Pu, N., Zhao, G., Gao, S., Cui, Y., Xu, Y., Lv, Y., et al. (2018). Neutralizing TGF-beta promotes anti-tumor immunity of dendritic cells against pancreatic cancer by regulating T lymphocytes. Cent. Eur. J. Immunol. 43, 123-131. doi: 10.5114/ceji. 2018.77381

Ramakrishnan, R., Tyurin, V. A., Veglia, F., Condamine, T., Amoscato, A., Mohammadyani, D., et al. (2014). Oxidized lipids block antigen crosspresentation by dendritic cells in cancer. J. Immunol. 192, 2920-2931. doi: 10.4049/jimmunol.1302801

Reizis, B., Bunin, A., Ghosh, H. S., Lewis, K. L., and Sisirak, V. (2011). Plasmacytoid dendritic cells: recent progress and open questions. Annu. Rev. Immunol. 29, 163-183. doi: 10.1146/annurev-immunol-031210-101345

Reya, T., Morrison, S. J., Clarke, M. F., and Weissman, I. L. (2001). Stem cells, cancer, and cancer stem cells. Nature 414, 105-111. doi: 10.1038/35102167

Reynolds, G., and Haniffa, M. (2015). Human and mouse mononuclear phagocyte networks: a tale of two species? Front. Immunol. 6:330. doi: 10.3389/fimmu. 2015.00330

Riley, R. S., June, C. H., Langer, R., and Mitchell, M. J. (2019). Delivery technologies for cancer immunotherapy. Nat. Rev. Drug Discov. 18, 175-196. doi: 10.1038/ s41573-018-0006-Z

Roberts, E. W., Broz, M. L., Binnewies, M., Headley, M. B., Nelson, A. E., Wolf, D. M., et al. (2016). Critical role for CD103(+)/CD141(+) dendritic cells bearing CCR7 for tumor antigen trafficking and priming of $\mathrm{T}$ cell immunity in melanoma. Cancer Cell 30, 324-336. doi: 10.1016/j.ccell.2016.06.003

Rodrigues, P. F., Alberti-Servera, L., Eremin, A., Grajales-Reyes, G. E., Ivanek, R., and Tussiwand, R. (2018). Distinct progenitor lineages contribute to the heterogeneity of plasmacytoid dendritic cells. Nat. Immunol. 19, 711-722. doi: 10.1038/s41590-018-0136-9

Rosa, F. F., Pires, C. F., Kurochkin, I., Ferreira, A. G., Gomes, A. M., Palma, L. G., et al. (2018). Direct reprogramming of fibroblasts into antigen-presenting dendritic cells. Sci. Immunol. 3:eaau4292. doi: 10.1126/sciimmunol.aau 4292

Rosenberg, S. A., Yang, J. C., Sherry, R. M., Kammula, U. S., Hughes, M. S., Phan, G. Q., et al. (2011). Durable complete responses in heavily pretreated patients with metastatic melanoma using T-cell transfer immunotherapy. Clin. Cancer Res. 17, 4550-4557. doi: 10.1158/1078-0432.CCR-11-0116

Saadeh, D., Kurban, M., and Abbas, O. (2016). Plasmacytoid dendritic cell role in cutaneous malignancies. J. Dermatol. Sci. 83, 3-9. doi: 10.1016/j.jdermsci.2016. 05.008

Sachamitr, P., Hackett, S., and Fairchild, P. J. (2014). Induced pluripotent stem cells: challenges and opportunities for cancer immunotherapy. Front. Immunol. 5:176. doi: 10.3389/fimmu.2014.00176

Saito, T., Takayama, T., Osaki, T., Nagai, S., Suzuki, T., Sato, M., et al. (2008). Combined mobilization and stimulation of tumor-infiltrating dendritic cells and natural killer cells with Flt3 ligand and IL-18 in vivo induces systemic antitumor immunity. Cancer Sci. 99, 2028-2036. doi: 10.1111/j.1349-7006.2008. 00907.x

Salio, M., Palmowski, M. J., Atzberger, A., Hermans, I. F., and Cerundolo, V. (2004). CpG-matured murine plasmacytoid dendritic cells are capable of in vivo priming of functional CD8 $\mathrm{T}$ cell responses to endogenous but not exogenous antigens. J. Exp. Med. 199, 567-579. doi: 10.1084/jem.20031059

Salmon, H., Idoyaga, J., Rahman, A., Leboeuf, M., Remark, R., Jordan, S., et al. (2016). Expansion and activation of CD103(+) dendritic cell progenitors at the tumor site enhances tumor responses to therapeutic PD-L1 and BRAF inhibition. Immunity 44, 924-938. doi: 10.1016/j.immuni.2016.03.012

Santos, P. M., and Butterfield, L. H. (2018). Dendritic cell-based cancer vaccines. J. Immunol. 200, 443-449. doi: 10.4049/jimmunol.1701024

Sa-Nunes, A., and Oliveira, C. J. F. (2021). Dendritic cells as a disputed fortress on the tick-host battlefield. Trends Parasitol 37, 340-354. doi: 10.1016/j.pt.2020.11. 004

Satthaporn, S., Robins, A., Vassanasiri, W., El-Sheemy, M., Jibril, J. A., Clark, D., et al. (2004). Dendritic cells are dysfunctional in patients with operable breast cancer. Cancer Immunol. Immunother. 53, 510-518. doi: 10.1007/s00262-0030485-5

Saxena, M., and Bhardwaj, N. (2018). Re-emergence of dendritic cell vaccines for cancer treatment. Trends Cancer 4, 119-137. doi: 10.1016/j.trecan.2017.12.007

Scarlett, U. K., Cubillos-Ruiz, J. R., Nesbeth, Y. C., Martinez, D. G., Engle, X., Gewirtz, A. T., et al. (2009). In situ stimulation of CD40 and Toll-like receptor 3 transforms ovarian cancer-infiltrating dendritic cells from immunosuppressive 
to immunostimulatory cells. Cancer Res. 69, 7329-7337. doi: 10.1158/00085472.CAN-09-0835

Schlitzer, A., McGovern, N., Teo, P., Zelante, T., Atarashi, K., Low, D., et al. (2013). IRF4 transcription factor-dependent CD11b+ dendritic cells in human and mouse control mucosal IL-17 cytokine responses. Immunity 38, 970-983. doi: 10.1016/j.immuni.2013.04.011

Schreibelt, G., Bol, K. F., Westdorp, H., Wimmers, F., Aarntzen, E. H., Duivemande Boer, T., et al. (2016). Effective clinical responses in metastatic melanoma patients after vaccination with primary myeloid dendritic cells. Clin. Cancer Res. 22, 2155-2166. doi: 10.1158/1078-0432.CCR-15-2205

Segura, E., and Amigorena, S. (2013). Inflammatory dendritic cells in mice and humans. Trends Immunol. 34, 440-445. doi: 10.1016/j.it.2013.06.001

Segura, E., Touzot, M., Bohineust, A., Cappuccio, A., Chiocchia, G., Hosmalin, A., et al. (2013). Human inflammatory dendritic cells induce Th17 cell differentiation. Immunity 38, 336-348. doi: 10.1016/j.immuni.2012.10.018

Senju, S., Haruta, M., Matsumura, K., Matsunaga, Y., Fukushima, S., Ikeda, T., et al. (2011a). Generation of dendritic cells and macrophages from human induced pluripotent stem cells aiming at cell therapy. Gene Ther. 18, 874-883. doi: $10.1038 /$ gt.2011.22

Senju, S., Haruta, M., Matsunaga, Y., Fukushima, S., Ikeda, T., Takahashi, K., et al. (2009). Characterization of dendritic cells and macrophages generated by directed differentiation from mouse induced pluripotent stem cells. Stem Cells 27, 1021-1031. doi: 10.1002/stem.33

Senju, S., Matsunaga, Y., Fukushima, S., Hirata, S., Motomura, Y., Fukuma, D., et al. (2011b). Immunotherapy with pluripotent stem cell-derived dendritic cells. Semin Immunopathol. 33, 603-612. doi: 10.1007/s00281-011-0263-y

Sharma, P. K., Dmitriev, I. P., Kashentseva, E. A., Raes, G., Li, L., Kim, S. W., et al. (2018). Development of an adenovirus vector vaccine platform for targeting dendritic cells. Cancer Gene Ther. 25, 27-38. doi: 10.1038/s41417-017-0002-1

Shinde, P., Fernandes, S., Melinkeri, S., Kale, V., and Limaye, L. (2018). Compromised functionality of monocyte-derived dendritic cells in multiple myeloma patients may limit their use in cancer immunotherapy. Sci. Rep. 8:5705. doi: 10.1038/s41598-018-23943-w

Shindo, Y., Hazama, S., Maeda, Y., Matsui, H., Iida, M., Suzuki, N., et al. (2014). Adoptive immunotherapy with MUC1-mRNA transfected dendritic cells and cytotoxic lymphocytes plus gemcitabine for unresectable pancreatic cancer. J. Transl. Med. 12:175. doi: 10.1186/1479-5876-12-175

Silk, K. M., Silk, J. D., Ichiryu, N., Davies, T. J., Nolan, K. F., Leishman, A. J., et al. (2012). Cross-presentation of tumour antigens by human induced pluripotent stem cell-derived CD141(+)XCR1+ dendritic cells. Gene Ther. 19, 1035-1040. doi: $10.1038 /$ gt.2011.177

Sluijter, B. J., van den Hout, M. F., Koster, B. D., van Leeuwen, P. A., Schneiders, F. L., van de Ven, R., et al. (2015). Arming the melanoma sentinel lymph node through local administration of CpG-B and GM-CSF: recruitment and activation of BDCA3/CD141(+) dendritic cells and enhanced crosspresentation. Cancer Immunol. Res. 3, 495-505. doi: 10.1158/2326-6066.CIR14-0165

Small, E. J., Higano, C. S., Kantoff, P. W., Whitmore, J. B., Frohlich, M. W., and Petrylak, D. P. (2014). Time to disease-related pain and first opioid use in patients with metastatic castration-resistant prostate cancer treated with sipuleucel-T. Prostate Cancer Prostatic. Dis. 17, 259-264. doi: 10.1038/pcan. 2014.21

Spranger, S., Bao, R., and Gajewski, T. F. (2015). Melanoma-intrinsic beta-catenin signalling prevents anti-tumour immunity. Nature 523, 231-235. doi: 10.1038/ nature 14404

Squadrito, M. L., Cianciaruso, C., Hansen, S. K., and De Palma, M. (2018). EVIR: chimeric receptors that enhance dendritic cell cross-dressing with tumor antigens. Nat. Methods 15, 183-186. doi: 10.1038/nmeth.4579

Steinman, R. M. (2007). Dendritic cells: understanding immunogenicity. Eur. J. Immunol. 37(Suppl 1), S53-S60. doi: 10.1002/eji.200737400

Steinman, R. M. (2012). Decisions about dendritic cells: past, present, and future. Annu. Rev. Immunol. 30, 1-22. doi: 10.1146/annurev-immunol-100311102839

Steinman, R. M., and Banchereau, J. (2007). Taking dendritic cells into medicine. Nature 449, 419-426. doi: 10.1038/nature06175

Steinman, R. M., and Swanson, J. (1995). The endocytic activity of dendritic cells. J. Exp. Med. 182, 283-288. doi: 10.1084/jem.182.2.283
Swiecki, M., and Colonna, M. (2015). The multifaceted biology of plasmacytoid dendritic cells. Nat. Rev. Immunol. 15, 471-485. doi: 10.1038/nri3865

Takahashi, K., and Yamanaka, S. (2006). Induction of pluripotent stem cells from mouse embryonic and adult fibroblast cultures by defined factors. Cell 126, 663-676. doi: 10.1016/j.cell.2006.07.024

Tanyi, J. L., Bobisse, S., Ophir, E., Tuyaerts, S., Roberti, A., Genolet, R., et al. (2018). Personalized cancer vaccine effectively mobilizes antitumor $\mathrm{T}$ cell immunity in ovarian cancer. Sci. Transl. Med. 10:eaao5931. doi: 10.1126/scitranslmed. aao5931

Tel, J., Aarntzen, E. H., Baba, T., Schreibelt, G., Schulte, B. M., Benitez-Ribas, D., et al. (2013). Natural human plasmacytoid dendritic cells induce antigenspecific T-cell responses in melanoma patients. Cancer Res. 73, 1063-1075. doi: 10.1158/0008-5472.CAN-12-2583

Theisen, D. J., Ferris, S. T., Briseno, C. G., Kretzer, N., Iwata, A., Murphy, K. M., et al. (2019). Batf3-dependent genes control tumor rejection induced by dendritic cells independently of cross-presentation. Cancer Immunol. Res. 7, 29-39. doi: 10.1158/2326-6066.CIR-18-0138

Tjomsland, V., Spangeus, A., Sandstrom, P., Borch, K., Messmer, D., and Larsson, M. (2010). Semi mature blood dendritic cells exist in patients with ductal pancreatic adenocarcinoma owing to inflammatory factors released from the tumor. PLoS One 5:e13441. doi: 10.1371/journal.pone.0013441

Toniolo, P. A., Liu, S., Yeh, J. E., Ye, D. Q., Barbuto, J. A., and Frank, D. A. (2016). Deregulation of SOCS5 suppresses dendritic cell function in chronic lymphocytic leukemia. Oncotarget 7, 46301-46314. doi: 10.18632/oncotarget. 10093

Trombetta, E. S., and Mellman, I. (2005). Cell biology of antigen processing in vitro and in vivo. Annu. Rev. Immunol. 23, 975-1028. doi: 10.1146/annurev. immunol.22.012703.104538

Tsuchiya, N., Zhang, R., Iwama, T., Ueda, N., Liu, T., Tatsumi, M., et al. (2019). Type I interferon delivery by ipsc-derived myeloid cells elicits antitumor immunity via XCR1(+) dendritic cells. Cell Rep. 29, 162-175.e169. doi: 10.1016/ j.celrep.2019.08.086

Tullett, K. M., Leal Rojas, I. M., Minoda, Y., Tan, P. S., Zhang, J. G., Smith, C., et al. (2016). Targeting CLEC9A delivers antigen to human CD141(+) DC for CD4(+) and CD8(+)T cell recognition. JCI Insight 1:e87102. doi: 10.1172/jci. insight.87102

Tyurin, V. A., Cao, W., Tyurina, Y. Y., Gabrilovich, D. I., and Kagan, V. E. (2011). Mass-spectrometric characterization of peroxidized and hydrolyzed lipids in plasma and dendritic cells of tumor-bearing animals. Biochem. Biophys. Res. Commun. 413, 149-153. doi: 10.1016/j.bbrc.2011.08.074

van Beek, J. J. P., Florez-Grau, G., Gorris, M. A. J., Mathan, T. S. M., Schreibelt, G., Bol, K. F., et al. (2020). Human pDCs are superior to cDC2s in attracting cytolytic lymphocytes in melanoma patients receiving DC vaccination. Cell Rep. 30, 1027-1038 e1024. doi: 10.1016/j.celrep.2019.12.096

Van der Jeught, K., Bialkowski, L., Daszkiewicz, L., Broos, K., Goyvaerts, C., Renmans, D., et al. (2015). Targeting the tumor microenvironment to enhance antitumor immune responses. Oncotarget 6, 1359-1381. doi: 10.18632/ oncotarget.3204

Van der Jeught, K., De Koker, S., Bialkowski, L., Heirman, C., Tjok Joe, P., Perche, F., et al. (2018). Dendritic Cell Targeting mRNA Lipopolyplexes Combine Strong Antitumor T-Cell Immunity with Improved Inflammatory Safety. ACS Nano 12, 9815-9829. doi: 10.1021/acsnano.8b00966

Van der Jeught, K., Joe, P. T., Bialkowski, L., Heirman, C., Daszkiewicz, L., Liechtenstein, T., et al. (2014). Intratumoral administration of mRNA encoding a fusokine consisting of IFN-beta and the ectodomain of the TGF-beta receptor II potentiates antitumor immunity. Oncotarget 5, 10100-10113. doi: 10.18632/ oncotarget. 2463

van der Waart, A. B., Fredrix, H., van der Voort, R., Schaap, N., Hobo, W., and Dolstra, H. (2015). siRNA silencing of PD-1 ligands on dendritic cell vaccines boosts the expansion of minor histocompatibility antigen-specific CD8(+) $\mathrm{T}$ cells in NOD/SCID/IL2Rg(null) mice. Cancer Immunol. Immunother. 64, 645-654. doi: 10.1007/s00262-015-1668-6

Van Lint, S., Renmans, D., Broos, K., Dewitte, H., Lentacker, I., Heirman, C., et al. (2015). The ReNAissanCe of mRNA-based cancer therapy. Exp. Rev. Vaccines 14, 235-251. doi: 10.1586/14760584.2015.957685

Van Lint, S., Renmans, D., Broos, K., Goethals, L., Maenhout, S., Benteyn, D., et al. (2016). Intratumoral Delivery of TriMix mRNA Results in T-cell Activation 
by Cross-Presenting Dendritic Cells. Cancer Immunol Res 4, 146-156. doi: 10.1158/2326-6066.CIR-15-0163

Van Lint, S., Wilgenhof, S., Heirman, C., Corthals, J., Breckpot, K., Bonehill, A., et al. (2014). Optimized dendritic cell-based immunotherapy for melanoma: the TriMix-formula. Cancer Immunol. Immunother. 63, 959-967. doi: 10.1007/ s00262-014-1558-3

Van Nuffel, A. M., Corthals, J., Neyns, B., Heirman, C., Thielemans, K., and Bonehill, A. (2010). Immunotherapy of cancer with dendritic cells loaded with tumor antigens and activated through mRNA electroporation. Methods Mol. Biol. 629, 405-452. doi: 10.1007/978-1-60761-657-3_27

VandenDriessche, T., Thorrez, L., Naldini, L., Follenzi, A., Moons, L., Berneman, Z., et al. (2002). Lentiviral vectors containing the human immunodeficiency virus type-1 central polypurine tract can efficiently transduce nondividing hepatocytes and antigen-presenting cells in vivo. Blood 100, 813-822. doi: 10. 1182/blood.v100.3.813

Vanmeerbeek, I., Sprooten, J., De Ruysscher, D., Tejpar, S., Vandenberghe, P., Fucikova, J., et al. (2020). Trial watch: chemotherapy-induced immunogenic cell death in immuno-oncology. Oncoimmunology 9:1703449. doi: 10.1080/ 2162402X.2019.1703449

Varypataki, E. M., Silva, A. L., Barnier-Quer, C., Collin, N., Ossendorp, F., and Jiskoot, W. (2016). Synthetic long peptide-based vaccine formulations for induction of cell mediated immunity: a comparative study of cationic liposomes and PLGA nanoparticles. J. Control Release 226, 98-106. doi: 10.1016/j.jconrel. 2016.02.018

Veglia, F., Tyurin, V. A., Mohammadyani, D., Blasi, M., Duperret, E. K., Donthireddy, L., et al. (2017). Lipid bodies containing oxidatively truncated lipids block antigen cross-presentation by dendritic cells in cancer. Nat. Commun. 8:2122. doi: 10.1038/s41467-017-02186-9

Verbeke, R., Lentacker, I., Breckpot, K., Janssens, J., Van Calenbergh, S., De Smedt, S. C., et al. (2019). Broadening the message: a nanovaccine co-loaded with messenger rna and alpha-galcer induces antitumor immunity through conventional and natural killer T cells. ACS Nano 13, 1655-1669. doi: 10.1021/ acsnano. $8 \mathrm{~b} 07660$

Verbeke, R., Lentacker, I., Wayteck, L., Breckpot, K., Van Bockstal, M., Descamps, B., et al. (2017). Co-delivery of nucleoside-modified mRNA and TLR agonists for cancer immunotherapy: Restoring the immunogenicity of immunosilent mRNA. J. Control Release 266, 287-300. doi: 10.1016/j.jconrel.2017.09.041

Villani, A. C., Satija, R., Reynolds, G., Sarkizova, S., Shekhar, K., Fletcher, J., et al. (2017). Single-cell RNA-seq reveals new types of human blood dendritic cells, monocytes, and progenitors. Science 356:eah4573. doi: 10.1126/science. aah4573

Vopenkova, K., Mollova, K., Buresova, I., and Michalek, J. (2012). Complex evaluation of human monocyte-derived dendritic cells for cancer immunotherapy. J. Cell Mol Med. 16, 2827-2837. doi: 10.1111/j.15824934.2012.01614.x

Wang, J., Iwanowycz, S., Yu, F., Jia, X., Leng, S., Wang, Y., et al. (2016). microRNA-155 deficiency impairs dendritic cell function in breast cancer. Oncoimmunology 5:e1232223. doi: 10.1080/2162402X.2016.123 2223

Wculek, S. K., Amores-Iniesta, J., Conde-Garrosa, R., Khouili, S. C., Melero, I., and Sancho, D. (2019). Effective cancer immunotherapy by natural mouse conventional type-1 dendritic cells bearing dead tumor antigen. J. Immunother. Cancer 7:100. doi: 10.1186/s40425-019-0565-5

Wculek, S. K., Cueto, F. J., Mujal, A. M., Melero, I., Krummel, M. F., and Sancho, D. (2020). Dendritic cells in cancer immunology and immunotherapy. Nat. Rev. Immunol. 20, 7-24. doi: 10.1038/s41577-019-0210-z

Wilgenhof, S., Corthals, J., Heirman, C., van Baren, N., Lucas, S., Kvistborg, P., et al. (2016). Phase II study of autologous monocyte-derived mRNA electroporated dendritic Cells (TriMixDC-MEL) plus ipilimumab in patients with pretreated advanced melanoma. J. Clin. Oncol. 34, 1330-1338. doi: 10.1200/JCO.2015.63. 4121
Wilgenhof, S., Van Nuffel, A. M. T., Benteyn, D., Corthals, J., Aerts, C., Heirman, C., et al. (2013). A phase IB study on intravenous synthetic mRNA electroporated dendritic cell immunotherapy in pretreated advanced melanoma patients. Ann. Oncol. 24, 2686-2693. doi: 10.1093/annonc/mdt245

Willemen, Y., Versteven, M., Peeters, M., Berneman, Z. N., and Smits, E. L. J. (2020). Ribonucleic acid engineering of dendritic cells for therapeutic vaccination: ready ' $\mathrm{N}$ able to improve clinical outcome? Cancers (Basel) 12:299. doi: $10.3390 /$ cancers 12020299

Williams, J. W., Tjota, M. Y., Clay, B. S., Vander Lugt, B., Bandukwala, H. S., Hrusch, C. L., et al. (2013). Transcription factor IRF4 drives dendritic cells to promote Th2 differentiation. Nat. Commun. 4:2990. doi: 10.1038/ncomms 3990

Wollenberg, A., Kraft, S., Hanau, D., and Bieber, T. (1996). Immunomorphological and ultrastructural characterization of Langerhans cells and a novel, inflammatory dendritic epidermal cell (IDEC) population in lesional skin of atopic eczema. J. Invest. Dermatol. 106, 446-453. doi: 10.1111/1523-1747. ep12343596

Yanagisawa, R., Koizumi, T., Koya, T., Sano, K., Koido, S., Nagai, K., et al. (2018). WT1-pulsed dendritic cell vaccine combined with chemotherapy for resected pancreatic cancer in a phase i study. Anticancer Res. 38, 2217-2225. doi: 10. 21873/anticanres. 12464

Yang, J., Shangguan, J., Eresen, A., Li, Y., Wang, J., and Zhang, Z. (2019). Dendritic cells in pancreatic cancer immunotherapy: Vaccines and combination immunotherapies. Pathol. Res. Pract. 215:152691. doi: 10.1016/j.prp.2019. 152691

Yang, Y. (2015). Cancer immunotherapy: harnessing the immune system to battle cancer. J. Clin. Invest. 125, 3335-3337. doi: 10.1172/JCI83871

Yarchoan, M., Huang, C. Y., Zhu, Q., Ferguson, A. K., Durham, J. N., Anders, R. A., et al. (2020). A phase 2 study of GVAX colon vaccine with cyclophosphamide and pembrolizumab in patients with mismatch repair proficient advanced colorectal cancer. Cancer Med. 9, 1485-1494. doi: 10.1002/cam4.2763

Zelenay, S., van der Veen, A. G., Bottcher, J. P., Snelgrove, K. J., Rogers, N., Acton, S. E., et al. (2015). Cyclooxygenase-dependent tumor growth through evasion of immunity. Cell 162, 1257-1270. doi: 10.1016/j.cell.2015.08.015

Zhang, R., Liu, T. Y., Senju, S., Haruta, M., Hirosawa, N., Suzuki, M., et al. (2015). Generation of mouse pluripotent stem cell-derived proliferating myeloid cells as an unlimited source of functional antigen-presenting cells. Cancer Immunol. Res. 3, 668-677. doi: 10.1158/2326-6066.CIR-14-0117

Zhao, F., Zhang, R., Wang, J., Wu, D., Pan, M., Li, M., et al. (2017). Effective tumor immunity to melanoma mediated by B16F10 cancer stem cell vaccine. Int. Immunopharmacol. 52, 238-244. doi: 10.1016/j.intimp.2017.09.019

Zilionis, R., Engblom, C., Pfirschke, C., Savova, V., Zemmour, D., Saatcioglu, H. D., et al. (2019). Single-Cell Transcriptomics of Human and Mouse Lung Cancers Reveals Conserved Myeloid Populations across Individuals and Species. Immunity 50, 1317-1334.e1310. doi: 10.1016/j.immuni.2019.03.009

Conflict of Interest: HW and NQ were employed by the company Hangzhou Biaomo Biosciences Co., Ltd., Hangzhou, China and Asia Stem Cell Therapies Co., Limited, Shanghai, China. MJ was employed by the company Hangzhou Biaomo Biosciences Co., Ltd., Hangzhou, China.

The remaining authors declare that the research was conducted in the absence of any commercial or financial relationships that could be construed as a potential conflict of interest.

Copyright $\odot 2021$ Salah, Wang, Li, Ji, Ou, Qi and Wu. This is an open-access article distributed under the terms of the Creative Commons Attribution License (CC BY). The use, distribution or reproduction in other forums is permitted, provided the original author(s) and the copyright owner(s) are credited and that the original publication in this journal is cited, in accordance with accepted academic practice. No use, distribution or reproduction is permitted which does not comply with these terms. 